\title{
'Ethni(City) \\ Identity and the Shopping Centre in the Contemporary Ethnoburb
}

by

\author{
Allan Paul Baniña, B.A.S. (Carleton) \\ ₹ \\ A thesis submitted to the graduate faculty at the \\ School of Architecture, Carleton University, \\ in partial fulfilment of the requirements \\ for the degree of
}

Master of Architecture Professional

Carleton University

Ottawa, Ontario, Canada

May 30, 2006

CCopyright

2006, Allan Paul Baniña 


\section{Acknowledgements:}

Many thanks to Professor Kariouk for his inspiration and guidance; to my colleagues at the School of Architecture for their friendship and support; and especially to my parents and family for instilling in me a love of learning. 


\section{Abstract}

Ethnic enclaves have been a part of the Canadian urban landscape for over a century, but recent demographic shifts in immigration to Canada have changed these settlements from predominantly urban and working class areas to suburban middle-class neighbourhoods. The contemporary ethnic suburb, or "ethnoburb," although spatially and economically different from traditional "Chinatowns" or "Little Italies," still needs to serve the desires of its residents for public spaces to express collectivity. This feat is not easily attained in the suburban landscape, which is dominated by private land ownership.

Using the case study of Toronto's Chinese ethnoburb-located in the edge-city of Markham, Ontario-this thesis explores sociological and cultural paradigms of the ethnic suburb relative to civic participation and transnational identity. The particular focus of this thesis study is the ethnic shopping centre, which is the architectural centre of these suburban communities. This study will investigate ways in which these centres may surpass their mere retail/economic roles and (more fully) embrace their existing socio-cultural functions within their communities. This project proposes the creation of new architectural typologies that aim to embrace and adequately respond to the needs of the new urban phenomenon of the ethnoburb. 


\section{TABLE OF CONTENTS}

INTRODUCTION

PART 1 EVOLUTION OF THE SPATIAL DIMENSION OF ETHNICITY IN

CANADA

1.1 Spatial study of Ethnicity in North American Cities

1.2 Development of Ethnic Enclaves in Canada: Segregation or Stronghold? 10

1.3 Ethnic Settlements and Government Policy

1.4 Contemporary Ethnic-Enclave Building

PART 2 CASE STUDY: TORONTO'S CHINESE ENCLAVES.

2.1 Kensington to Ethnoburbia

2.2 Contemporary Chinese Settlement Patterns in Suburban Toronto

PART 3 TRANSNATIONALISM, SOCIAL FIELDS, AND THE ETHNOBURB..29

3.1 Mobility of People and Goods in the Ethnoburb

3.2 Suburban landscapes and Transnationality

PART 4 SHOPPING AND THE OTHER: ETHNIC MALLS AND THE IDENTITY OF SUBURBIA .38

4.1 Ethnic Malls in the Lineage of Suburban Retail Geography 38

4.2 Shopping and Suburban Identity 42

4.3 Post-Shoppers and the Reclamation of Commodified Space 45

4.4 Artificial Urbanity and the Shopping Centre 47

4.5 Ethnic Malls and Futures in Ethnoburbia (Why Undertake This Design Project?)

PART 5 DESIGN PROJECT.

5.1 Site: Market Village, Markham, Ontario, Canada

5.2 Design Intentions and Building Program 
5.3 Design Strategy

$\begin{array}{ll}5.4 \text { Cultural Anchor (Case 1) } & 67\end{array}$

5.5 Food Court / Community Theatre (case 2) 74

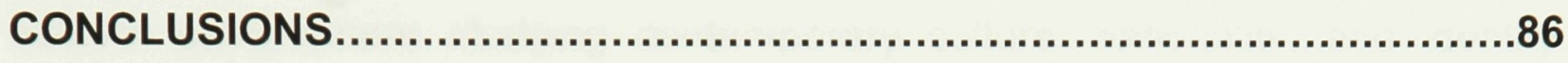

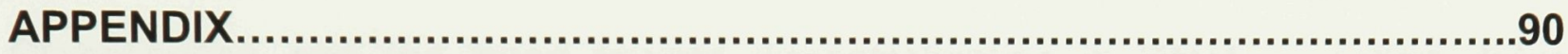

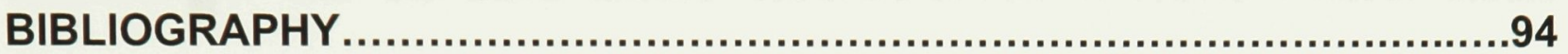




\section{INTRODUCTION}

The diversity of current Canadian society has precipitated great interest among cultural geographers studying contemporary culture, nationality, and identity. Globalization and the trend toward decentralization in Western nation-states have led to increased immigration and have, in turn, led to numerous discussions regarding the validity of assimilation theories relative to immigration and settlement, such as that of the American melting pot and the rise of conditions of transnational identities, such as Canadian dual citizenship. ${ }^{1}$ Related to, and very nearly underpinning, these topics are ethnic suburban communities or "ethnoburbs." ${ }^{2}$ Home to an increasingly mobile and economically prosperous immigrant population, the ethnoburb represents a spatial manifestation of its inhabitants' transnational lifestyles. The following study will attempt to provide (a) a view of the forces that have led to the creation of these "modern" urban ethnic enclaves, and, more specifically, the contemporary ethnic suburb; and (b) suggest ways in which urban planning and architecture may have a hand in responding to the spatial needs of this new urban typology.

Part One chronicles the development of urban ethnic enclaves in the past one hundred years since immigration became a force in Canadian demographics in

\footnotetext{
${ }^{1}$ Vincent Miller, "Mobile Chinatowns: The Future of Communities in a Global Space of Flows," Social Issues 2.1 (Jan. 2004): 1, online, Internet, 2 Mar. 2006. Available http://www.whb.co.uk/socialissues/vol2vm.htm.

${ }^{2}$ The term "ethnoburb" was first used by American geographer Wei Li in the 1990's to describe and distinguish the L.A. suburban Chinese community forming in the San Fernando Valley area from the older urban L.A. chinatown.
} 
order to understand the socio-political influences behind their formations. This background information will serve to contrast the differences between the modern ethnoburb and its pre-war, urban predecessors.

Part Two is a case study of the Chinese-Canadian experience in Toronto, from the early days of migrant labourers to the present-day business-class immigrants. The Chinese have been chosen for this case study not only because of their large concentrations in Canadian cities but also becauseperhaps more so than other group-Chinese ethnoburbs are prolific and established and, hence, can be readily studied. Examples of these Chinese ethnoburbs exist as edge cities of Vancouver and Toronto, specifically Richmond, British Columbia and Markham, Ontario respectively.

Part Three looks at the physical form of the ethnic suburb and how transnational identities (i.e., identities that have roots in more than one country) have shaped suburbia and conversely how the auto-scaled, suburban landscape has shaped a new type of ethnic space.

Part Four shifts to an architectural scale to investigate the development of the suburban shopping centre and both chronicles and analyzes its role in suburban social-identity formation. Additionally, ethnic shopping centres will be contrasted and compared to their mainstream counterparts in order to understand the role they play in the particular social environment of the ethnoburb. 
Part Five highlights a design proposition for the Market Village Shopping Centre, a Chinese mall located in Markham, Ontario. The project attempts to respond architecturally to this suburb's lack of accommodation for relevant public spaces and proposes interventions by which ethnoburb, transnational identity and civic participation might thrive. 


\section{PART 1 EVOLUTION OF THE SPATIAL DIMENSION OF ETHNICITY IN CANADA}

\subsection{Spatial Study of Ethnicity in North American Cities}

The increasingly multi-ethnic character of Canadian society has brought issues of diversity and, namely, concerns over the social politics of the occupation of urban space to the forefront of cultural geography discourse. These concerns have implications for minority communities gaining in size and prominence. Appropriation of space is a political act in that access to space is, fundamentally, related to power; changing the allocations of space is inherently related to a changing society. ${ }^{3}$ In the North American city, minority communities competing for space are often ethnic populations or new immigrants. Consequently, the study of ethnicity in North America is a process best understood when integrated into a spatial, urban framework, and ethnic enclaves have a significant role to play in the understanding of social dynamics in multicultural societies such as Canada. ${ }^{4}$

${ }^{3}$ Leslie Kanes Weissman, Discrimination by Design: A Feminist Critique of the Man-Made Environment (Urbana, Illinois: University of Illinois Press, 1992) 1.

${ }^{4}$ Robert Harnery, Gathering Place: Peoples and Neighbourhoods of Toronto 1834-1945 (Toronto: Multicultural History Society of Ontario, 1985) 6. 


\subsection{Development of Ethnic Enclaves in Canada: Segregation or Stronghold?}

Ethnic enclaves have been present in the Canadian urban landscape since the early days of immigration. In order to comprehend the development of these neighbourhoods, it is important to recall the attitudes towards immigration that led to their creation. The immigrant experience in pre-war Canada was one marked with ordeals of xenophobia and systemic racism. The social segregation that arose from this intolerance led to spatial, urban segregation resulting in the rise of urban ethnic neighbourhoods.

Immigration to Canada proceeded in successive waves during the nineteenth and twentieth centuries. Canadian immigration policy systematically sought to discourage non-British and -American immigrants away from cities and into labour-intensive, rural industries. Immigrants who did manage to arrive in cities tended to settle in ethnically specific clusters. These settlements emerged for a number of reasons: the sense of emotional security gained from living amongst fellow expatriates; the facility of common language; and, most importantly, the desire to maintain cultural and religious traditions. ${ }^{5}$ In this manner, the neighbourhood functioned as a little homeland, a spatial entity based on its inhabitants' set of common values, traditions, and world view. The enclaves were not only separate physically from the mainstream of a city but were also separate socially. Areas containing employment, as well as ethnically specific

\footnotetext{
5 Harnery 8.
} 
residential areas, registered differently in one's personal city hierarchy, depending on a person's personal affiliations, thus creating different social and geographical mappings of the city. For example, the first Bulgarian-English dictionary published in Toronto included phrases on how to take the streetcar to King Street East "where the Macedonians live". ${ }^{6}$ With no references to other neighbourhoods in the city, the dictionary encapsulated the socio-spatial perceptions common to immigrant groups of the period, categorizing areas outside ethnically friendly neighbourhoods as unfamiliar and even threatening places. This geographical assignment of neighbourhoods to different communities allowed a fear of other to translate into a fear of place, further aggravating socio-spatial segregation. ${ }^{7}$

\subsection{Ethnic Settlements and Government Policy}

Urban ethnic settlement patterns in Canada have gone through many evolutions following shifts in national immigration policies. Toronto in the late 19th century was a city that reflected the cultural homogeneity of the country at large in which only eight per cent of the population was not of British or French ancestry. By the 1920s, the figure had climbed to 20 per cent as a result of an influx of immigrants from Central and Southern Europe, and East Asia. The foreign population consisted of Jews, Germans, Italians, Chinese, and various Slavic

\footnotetext{
${ }^{6}$ Harney 15.

${ }^{7}$ David Sibley "Outsiders in Society and Space," In Inventing Places: Studies in Cultural Geography. (Sydney: Longman Cheshire. 1992) 112.
} 
groups all living in visible residential concentrations in the core of the city. These ethnic settlements created the patterns of separateness that foreshadowed the post-war ethnic enclaves built in the city.

A group's tendency towards spatial segregation discernibly depended on its degree of acceptance by the mainstream Anglo-Canadian population. Italians, Chinese, Jews, and Slavs lived in highly concentrated areas in the city, while British immigrant settlement patterns were more evenly dispersed. This pattern corresponded to a group's perceived social status and ease of acculturation into the mainstream. Those who did not encounter systematic discrimination (English-speaking British and Americans) were not confined to enclaves. Conversely, those literally seen as foreign, and hence incapable of acculturation, were relegated to the marginal spaces of the city thus creating the social environment necessary for the development of the ethnic enclave. Prior to 1970 , these neighbourhoods tended to be compact, socio-spatial zones encompassing several city blocks, where a large number of immigrants from the same background lived, and where most of their cultural and religious institutions, businesses, and services were located. ${ }^{8}$ These small and dense settlements contrast highly with their modern suburban counterparts that have grown to envelop entire quadrants of the Greater Toronto Area.

\footnotetext{
${ }^{8}$ Paul Anisef and Michael Lanphier, The World in a City (Toronto: University of Toronto Press, 2003) 139.
} 
Calls for the cultural and religious assimilation of these ethnic enclaves were made in local publications and by citizens' groups. This opinion resonated in Canada before the Multiculturalism Act was recognized by the federal government in $1988 .^{9}$ Previously, ideas of citizenship came hand in hand with that of cultural conformity. Many demanded that these "foreign colonies," seen as urban blights, be eradicated and their populations dispersed. Nonetheless, ethnic enclaves, such as those of The Ward and Kensington Market (figures 1, 2), continued to play a central role in the social development of the immigrant communities that they housed by functioning as segregated, ethnically specific safe space in which its minority population felt comfort in its local majority.

\subsection{Contemporary Ethnic-Enclave Building}

Reforms to immigration policy reflecting more tolerant public attitudes in the 1950s started a new era of immigration in which the arrival of immigrants became more than just a labour-importation scheme. ${ }^{10}$ Perhaps the most important reform was the elimination of race, ethnicity, and country of origin as

\footnotetext{
${ }^{9}$ The Canadian Multiculturalism Act received royal assent on July $21^{\text {st }} 1988$. The policy states the Federal government's position towards the preservation, enhancement and sharing of Canadian's diverse ethnic traditions.

${ }^{10}$ Anisef 30-31.
} 


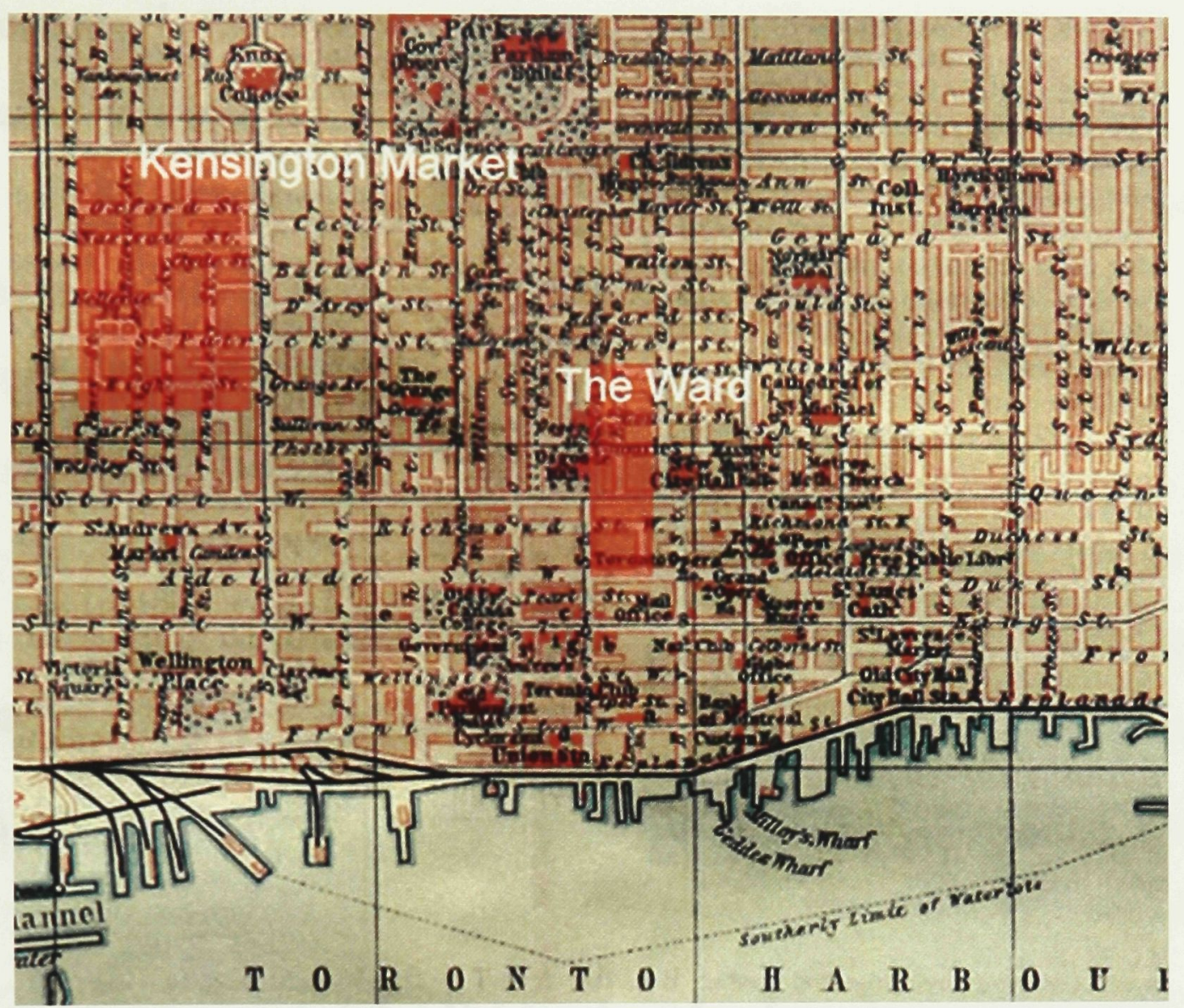

Figure 1: Map of Downtown Toronto late 1800's highlighting Kensington Market and The Ward immigrant areas.

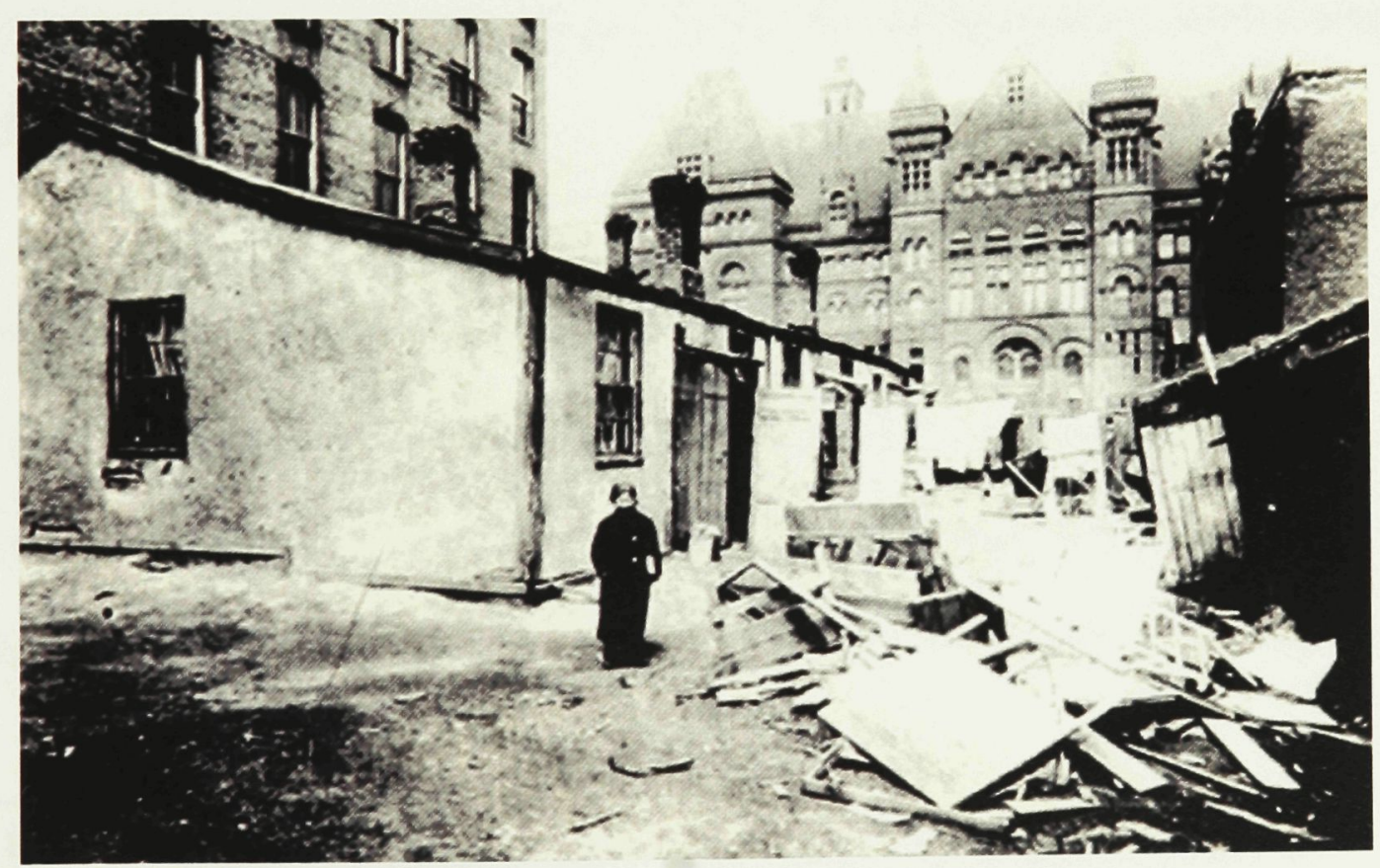

Figure 2: The Ward, Toronto c. 1911, Immigrant slums at exact location of Viljo Revell's 1965 New City Hall. E.J. Lennox' 1899 Richardson Romanesque city hall is visible behind the houses.

Harney, Robert. Gathering Place: Peoples and Neighbourhoods of Toronto 1834-1945 (Toronto: Multicultural History Society of Ontario, 1985) 150. 
criteria for entry. ${ }^{11}$ This change resulted in an influx of immigrants from Asia, the Caribbean, and elsewhere in the developing world. The Multiculturalism Act served to further reflect contemporary tolerant social attitudes towards immigration. The Act's objectives were to promote racial diversity and acknowledge the freedom of members of society to preserve, enhance, and share their cultural heritage. It is in this new social condition that the contemporary development and proliferation of ethnic enclaves should be studied; since systemic racism and discrimination is socially unacceptable, at least officially, it is significant to note that the creation and growth of ethnic enclaves is as strong as ever. For example, in suburban Toronto, the town of Markham now boasts an approximately thirty per cent Chinese population where twenty years ago that figure was less than five per cent. If discrimination was the driving force behind ethnic segregation in the past, the question now is: what has replaced discrimination as the driving force for contemporary ethnic-enclave building?

The contemporary clustering of ethnic groups in Canadian cities is sometimes viewed as analogous to the classic American ghetto. In reality, new enclaves differ from ghettos in that moving into an enclave of ethnic concentration is done by choice and there are exit options for the people living there. ${ }^{12}$ Contemporary

\footnotetext{
${ }^{11}$ Sheila L. Croucher, "Constructing the Image of Ethnic Harmony In Toronto, Canada: The Politics of Problem Definition and Nondefinition," Urban Affairs Review 32.3 (1997): 324.

${ }^{12}$ Nicholas Keung and Prithi Yelaja, "Knowing the Neighbours" Toronto Star 25 June 2005: B1,B4-5.
} 
enclaves emerge as ethnic communities become self-sufficient, complete with a wide range of businesses and services catering to dominant ethnic and linguistic groups. Ethnic enclaves, and ethnoburbs in particular, are now seen as a marker of an immigrant group's economic and social success, rather than as a product of its societal marginalization. A minority community's capacity to create its own institutions is seen by people, from both inside and outside the community, as a sign of stability and ownership. The establishment of these cultural anchors, such as social clubs, churches, and schools, demonstrates a group's tremendous capacity and talent to pool its resources and find ways to create community in its new environment. ${ }^{13}$

In their book, A World in a City, sociologists Paul Anisef and Michael Lanphier cite the importance of building social and cultural organizations in the creation of ethnic enclaves. The creation of both ethnically specific commercial and cultural services has been at the core of the desire of ethnic communities to maintain group settlements. When new immigrants arrive in a city, a common goal in determining suitable accommodation is to find a neighbourhood where they may develop social networks. These networks are most often found with people from the same ethnic background because of similar language and custom. The ethnic institution, such as the social club, employment agency, or religious organization, is a formalization of these networks. Through the establishment of institutions, moral support, and community-based employment and housing information services, opportunities for new immigrants are greatly enhanced. It

${ }^{13}$ Anisef 391. 
is this social support, along with the availability of ethnically specific goods and services that make the ethnic neighbourhood the attractive choice for new immigrants in their initial period of settlement. ${ }^{14}$

Criticisms of the proliferation of ethnic enclaves state that ethnoburbs present an image of an ideal that counters the (ideal) of multiculturalism. In this view, the desired cultural openness of multiculturalism is blocked by the (perception of a) guarded and isolated nature of the ethnoburb community. This criticism stems from the perception of the enclave as a fortress, built up by residents against the threat of cultural "Others." Culture is a multi-faceted and living entity; therefore, stasis of culture is not possible, vis-à-vis the inevitability of cultural syncretism in multi-ethnic settings. Ethnoburbs are not as culturally exclusive as the early urban ethnic neighbourhoods of the nineteenth and twentieth centuries; at least twenty to forty per cent of people currently living in these areas are from ethnicities other than the numerically dominant group. The visibility of an ethnoburb results from the concentration, not the exclusivity, of one ethnic group over the others. The ethnoburb presents a different space of multiculturalism where the label of "visible minority" has become archaic as a result of the numerical, collective majority of numerous ethnic communities. It is perhaps in the social environment of the ethnoburb that an improved multicultural society of equals has its future.

${ }^{14}$ Anisef 137. 


\section{PART 2 CASE STUDY: TORONTO'S CHINESE ENCLAVES}

\subsection{Kensington to Ethnoburbia}

Arriving in the early 1900s, Toronto's first sizable concentration of Chinese residents supported themselves through the hand laundry trade, which it ultimately monopolized. Between the years 1900 and 1923, Toronto saw exponential growth in the Chinese population, as well as an expansion of the range of Chinese business endeavours, which now included restaurants and grocery stores. The Chinese Reform Association, whose purpose was to lobby for reforms of the Manchu government in China, formed the institutional heart of the Queen Street East Chinatown (figure 3). The association and its members brought a critical mass of people to the area who would frequent the Chinese businesses along Queen Street. Without the association, there would not have been any draw for the Chinese community to shop in this area. However, after the downfall of the Manchu government in 1912, the association became defunct, causing the surrounding businesses to lose their clientele base, ultimately leading to bankruptcies. ${ }^{15}$ The death of this enclave demonstrates the symbiotic relationship between an ethnic enclave's retail and institutional anchors. The institutional structures of immigrant groups are neither uniform nor static across time; similarly, commercial ventures change with the forces of supply and demand, with these two factors inherently pushing and pulling the

\footnotetext{
${ }^{15}$ David Lai, Chinatowns: Towns within Cities in Canada (Vancouver: UBC Press, 1988) 97.
} 
physical boundaries of an enclave. The case of the Queen Street East Chinese community in Toronto is especially demonstrative of this evolution of the urban enclave. Perhaps more intriguing is how the fall of a government in China had an effect on settlement patterns of Chinese Canadians on the other side of the globe, thus demonstrating the transnational fields to which ethnic enclaves are inherently connected.

By the mid 1920s, the area known as "Chinatown proper" was centred on Elizabeth Street between Queen and Dundas Streets in the area once known as "The Ward" (figure 4). The area thrived as Chinese-owned businesses rushed to occupy storefronts formerly operated by Jewish-owned establishments. The Elizabeth Street area was once the epicentre of the Jewish community, which, upon making significant gains economically and socially over four decades, moved out of this original area of settlement into more spacious homes and businesses north of downtown. This cycle of immigrant settlement is a pattern that is commonly seen in cities; newer immigrant groups replace former groups who become established or assimilated and move on to better housing. The affordable rents and proximity to jobs in the downtown core that attracted the early Jewish immigrants to the neighbourhood also became attractive to succeeding groups of Chinese immigrants to the area. 


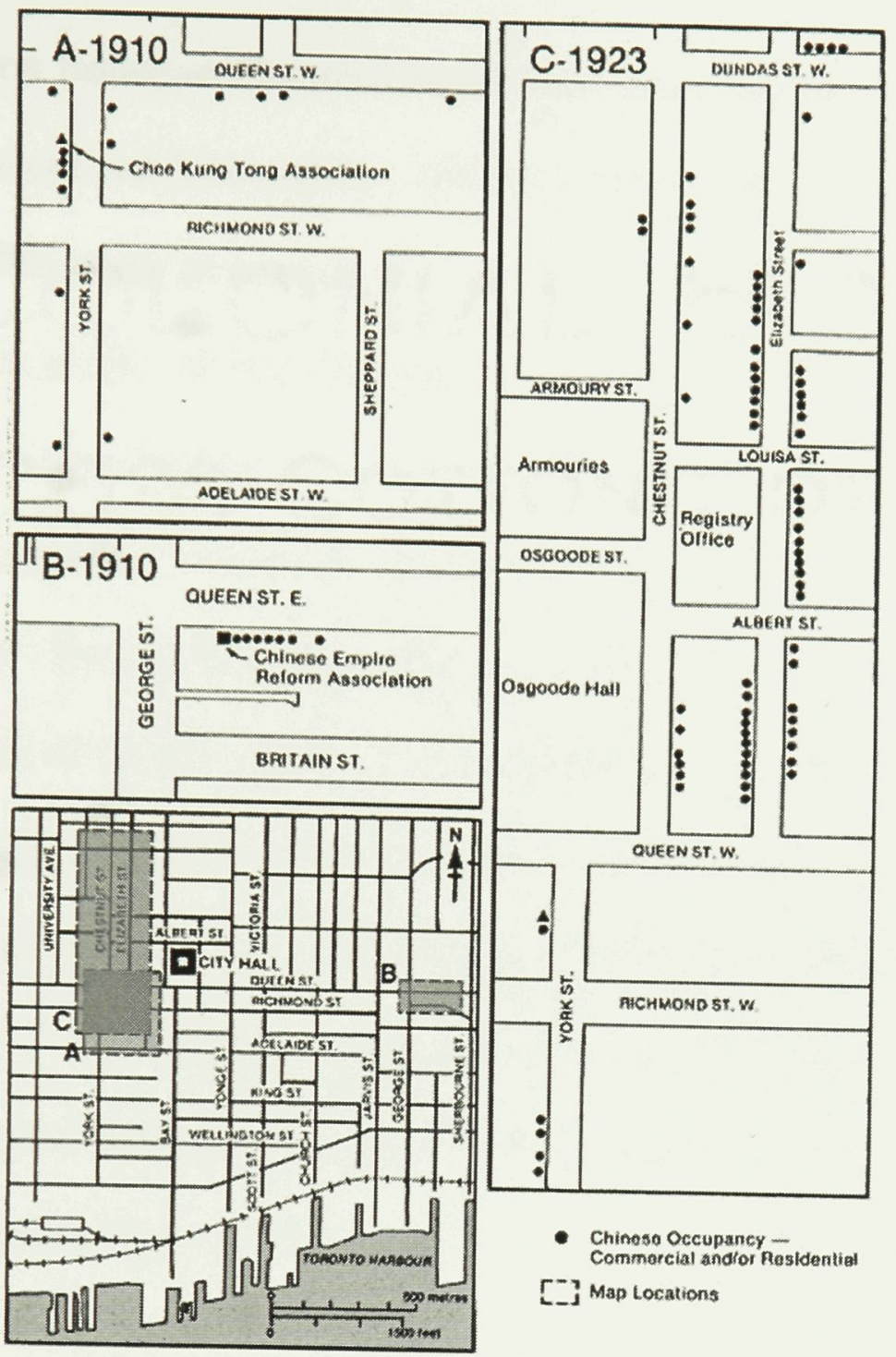

Figure 3: Toronto's Chinatowns 1910, 1923.

Lai, David. Chinatowns: Towns within

Cities in Canada (Vancouver: University of British Columbia Press, 1988) 98.

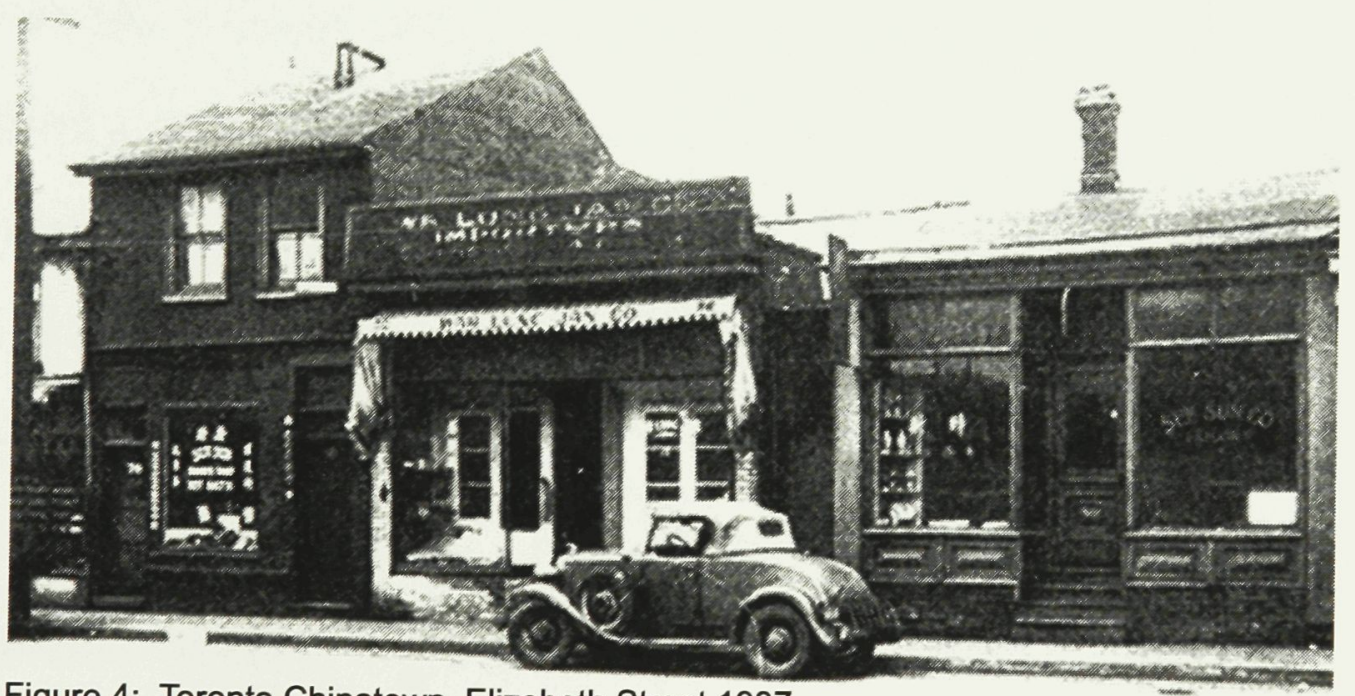

Figure 4: Toronto Chinatown, Elizabeth Street 1937

City of Toronto Archives. Elizabeth Street 1937.

Harney, Robert. Gathering Place: Peoples and Neighbourhoods of Toronto 1834-1945

(Toronto: Multicultural History Society of Ontario, 1985) 151. 
Relations between Chinese immigrants and "mainstream" Toronto society in the 1920s were not favourable. The increasing size of the Chinese population in the downtown area prompted the editor of Toronto's Saturday Night publication to warn the public of the Chinese influence on the city and advocate the policy of "keeping the Chinese on the move" so that no Chinese quarter could develop in Toronto proper. However, these harsh opinions and the outcome hoped for by its writer had the opposite effect, for they induced the Chinese businesses and residents to locate closer to one another for mutual protection. ${ }^{16}$ The Chinese community suffered more threats in 1923 when the Canadian government, influenced by popular anti-Chinese sentiment fuelled by cultural and religious post-WW I xenophobia, passed the Chinese Immigration Act. The bill prevented the entry of Chinese immigrants to Canada, signalling a decline in the growth of the Chinese-Canadian population.

After two decades of population decline, formal protests by the Committee for the Repeal of the Chinese Immigration Act were able to convince the Federal government to cancel the law. The committee was supported by Chinese and non-Chinese organizations such as both the Protestant and Catholic Church, the Council of Women, several members of Parliament, the Canadian Congress of Labour, and the Toronto Trades and Labour Councils. This new alliance with non-Chinese society was perhaps a result of the patriotic involvement of Canadian-born Chinese youths in the war effort. ${ }^{17}$ The revival of Toronto's

\footnotetext{
${ }^{16}$ Lai 97.

${ }^{17}$ Harney 171.
} 
Chinatown after the resumption of immigration happened slowly. In 1955, the construction of Toronto's present city hall eventually engulfed the Chinatown site (figures 5, 6), displacing the community once again. Reticent to protest the eviction, the Chinese community simply sought housing in the neighbourhood around Spadina and Kensington Market (figure 7), thus establishing a new, third Chinatown now known by the misnomer of "old" Chinatown.

\subsection{Contemporary Chinese Settlement Patterns in Suburban Toronto}

Presently, the Greater Toronto Area is home to approximately half a million people of Chinese descent. In the old city of Toronto, the community makes up ten per cent of the total population and is the city's largest visible minority group. The Toronto region is now home to four distinct areas recognized as "Chinatowns" by the number of culturally specific businesses and services serving predominantly Chinese clientele. ${ }^{18}$

It is easy to overlook the diversity within the Chinese community itself. Recent immigration to Canada has included large numbers of ethnic Chinese from Southeast Asia, the West Indies, and East Asia (e.g., Taiwan). Emigrants from Hong Kong have perhaps made the largest shift in demographics of the Chinese population in Canada. In the years leading up to Beijing's takeover of the former British Colony in 1997, the Canadian government launched an aggressive campaign to attract business-class people seeking to leave Hong Kong, which

\footnotetext{
${ }^{18}$ Harney 172.
} 

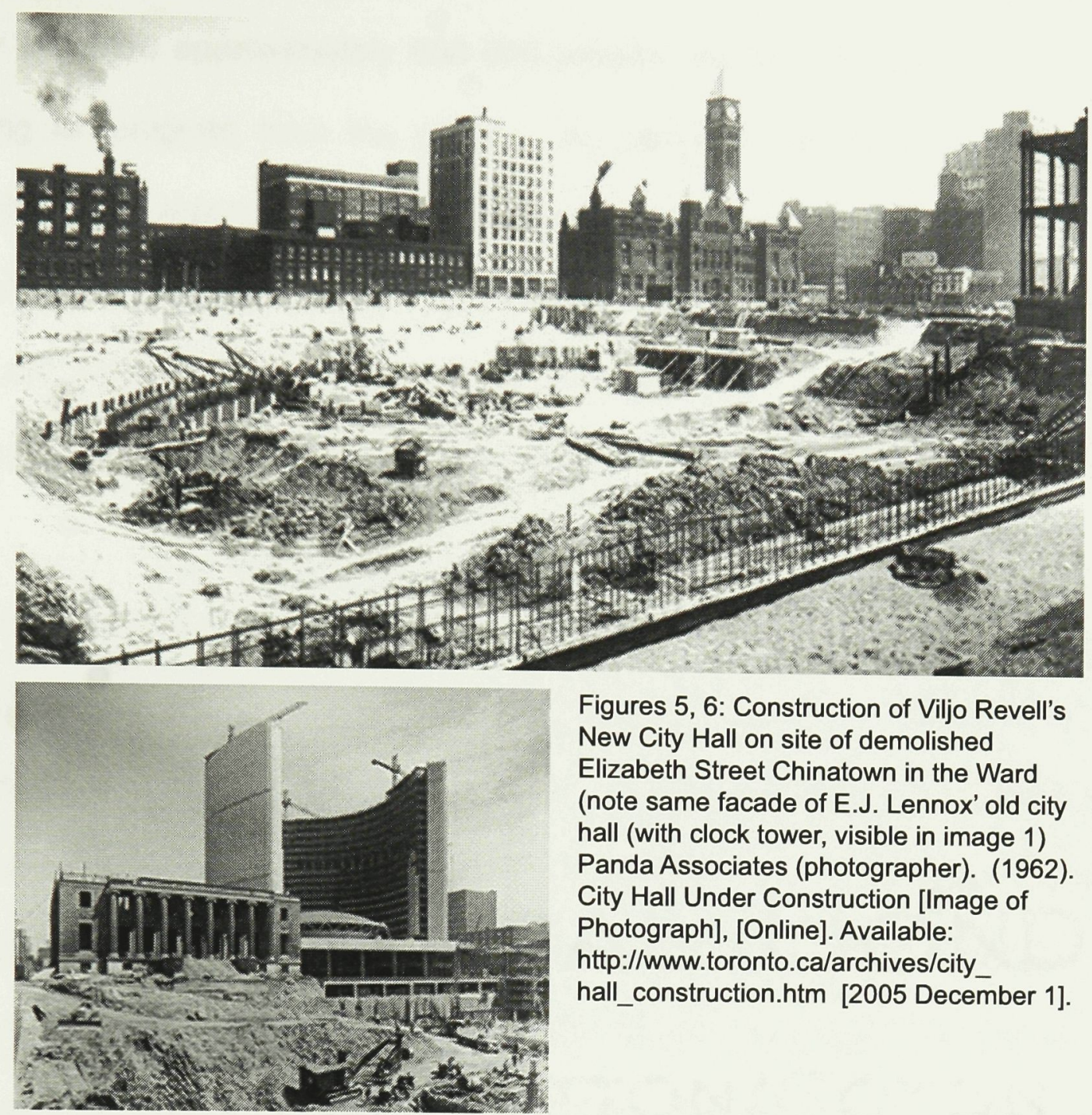

Figures 5, 6: Construction of Viljo Revell's New City Hall on site of demolished Elizabeth Street Chinatown in the Ward (note same facade of E.J. Lennox' old city hall (with clock tower, visible in image 1) Panda Associates (photographer). (1962). City Hall Under Construction [Image of Photograph], [Online]. Available: http://www.toronto.ca/archives/city_ hall_construction.htm [2005 December 1].

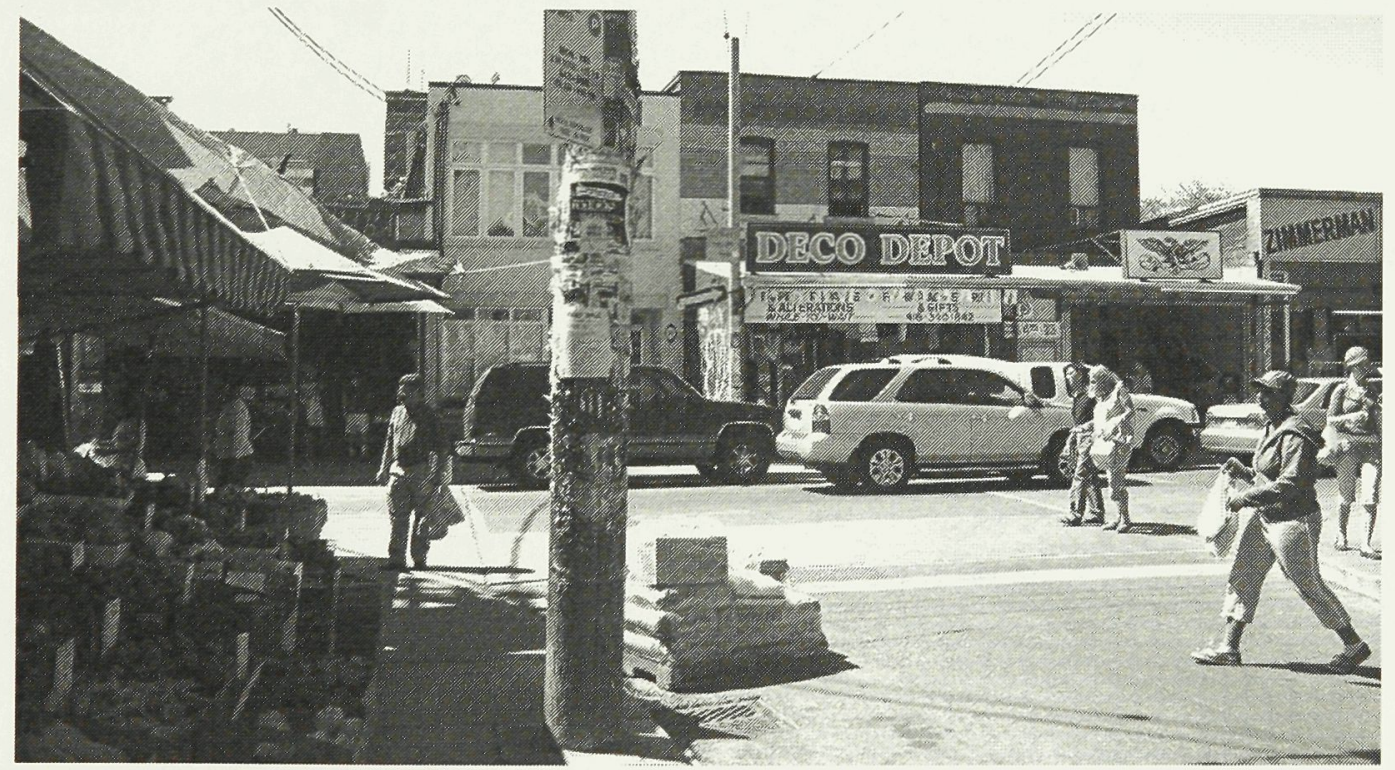

Figure 7: Kensington Market, Toronto. This neighbourhood along with the adjacent Spadina Avenue Chinatown has been the immigrant reception area of successive waves immigrants throughout the 19th and 20th centuries. Each community has left traces of their presence in these areas as attested to by the multi-cultural mix of businesses and cultural institutions in a five block quarter. 
directly attracted approximately 600000 people, equal to ten per cent of those choosing to emigrate from the colony. As wealthier sections of the Chinese population were able to emigrate, Canada became the preferred destination over the United States and Australia for reasons of the country's high standard of living and progressive attitudes towards immigration. Consequently, Canada attracted the bulk of Hong Kong's emigrants.

The new Hong Kong business-class arrivals put an unexpected twist on the development of ethnic enclaves in the city of Toronto. Welcomed by the government for their educational levels and occupational skills, this contingent of immigrants often had the economic resources to buy expensive housing in suburban communities such as Scarborough, Markham, and Richmond Hill (figures 8). These locales became the new Chinese reception areas since new immigrants often bypassed the traditional urban Chinatowns and settled directly in the suburbs. ${ }^{19}$ Through this process, compact ethnic clusters of self-sufficient, suburban communities were created, forming what Wei Li, Associate Professor of Asian Pacific American Studies at Arizona State University, termed "ethnoburbs" in her 1998 study of Los Angeles. ${ }^{20}$ These suburban Chinatowns have become a vital component of the Chinese network in the city, contributing to the community's new settlement pattern while undermining the traditional model of the North American city and its white suburbs (figure 9).

\footnotetext{
${ }^{19}$ Anisef 139.

${ }^{20}$ Wei Li, "Los Angeles's Chinese Ethnoburb: From Ethnic Service Center to Global Economy Outpost", Urban Geography, 29.6 (1998).
} 


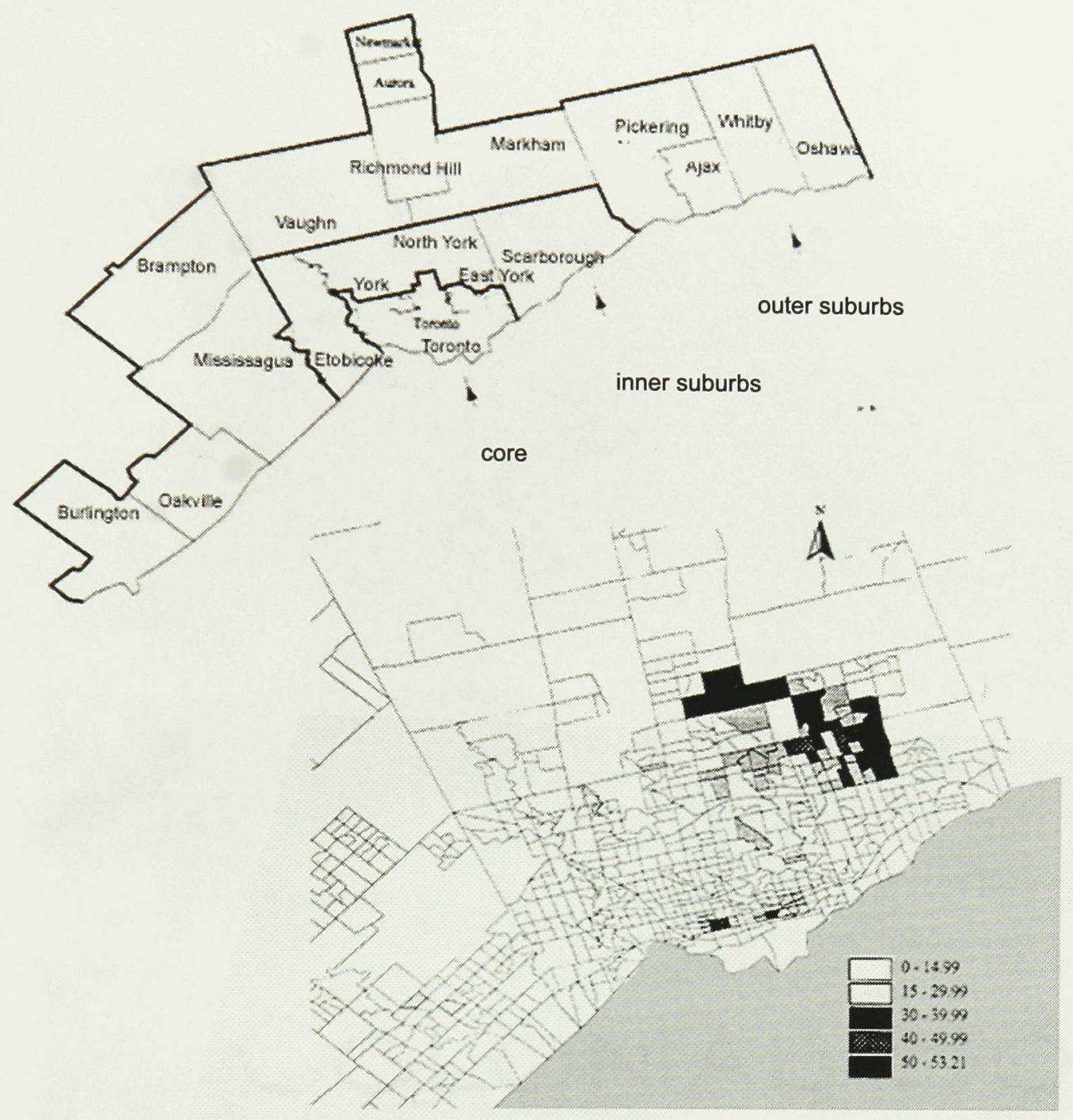

Figure 8: Chinese populations in suburban Greater Toronto Area municipalities Percentage of Chinese population by census tracts 1991.

Lo ,Lucia and Wang, Shuguang. "Settlement Patterns of Toronto's Chinese Immigrants: Convergence or Divergence?" Canadian Journal of Regional Science vol.20(1997): p. 49-72. 


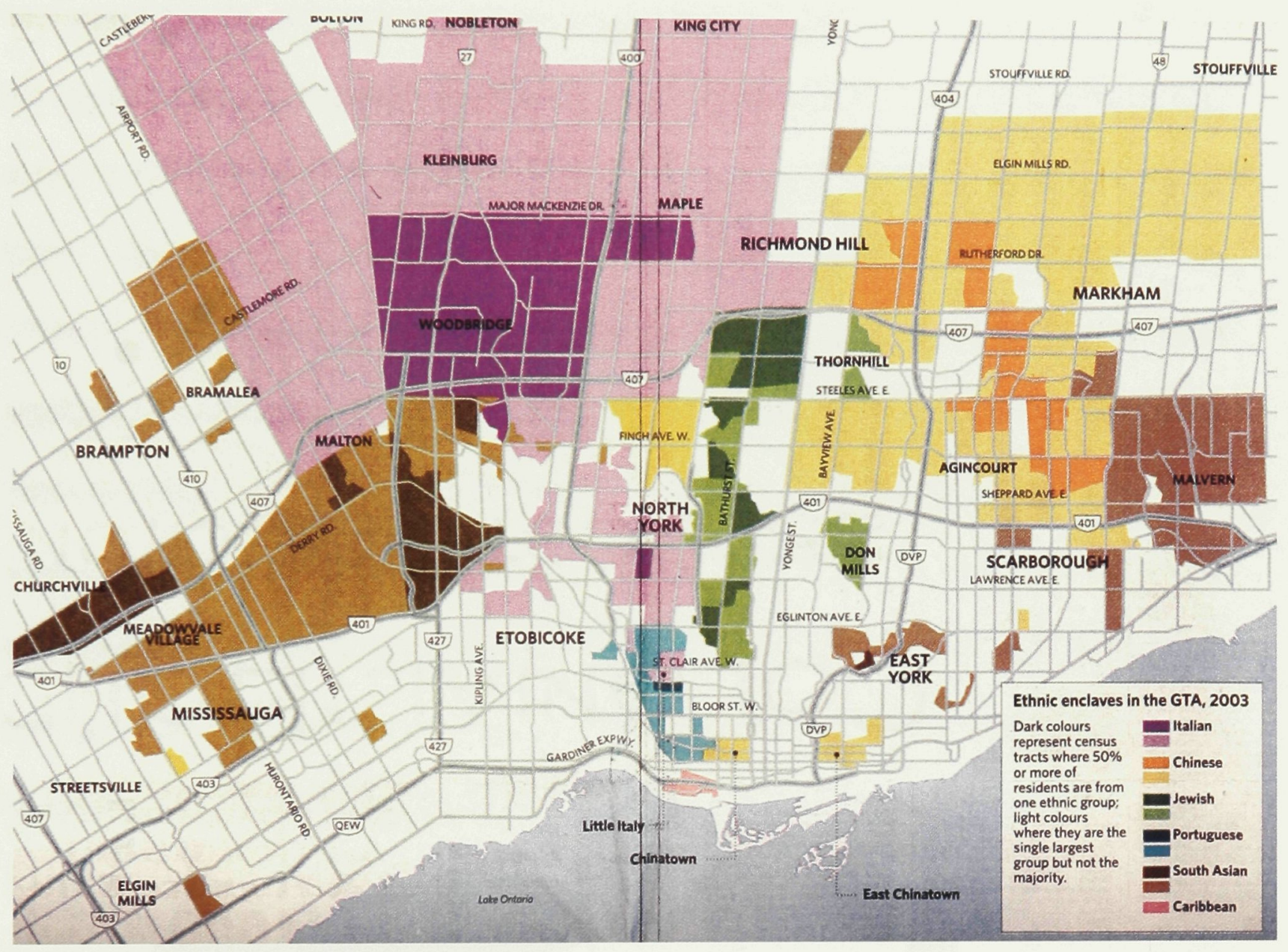

Figure 9: Map showing the location of ethnic enclaves in the Greater Toronto Area, 2003 Keung, Nicholas and Prithi Yelaja. "Knowing the Neighbours." Toronto Star. 23 June 2005: B1, B4-5. 
The suburbanization of this community has brought with it some of the same racial tensions witnessed in the establishment of Chinatowns in the last century. The Toronto suburb of Markham with its influx of Asian immigrants, and the subsequent building of "monster homes" and "Asian-theme" malls, has become a contested site by the original Anglo-Canadian population. In 1995 Carole Bell, the deputy mayor of Markham, warned that the prevalence of Chinese-language signs in the area's malls (figure 10) was prompting a Canadian version of "white flight." The use of a language other than English on signage had branded the Chinese newcomers as outsiders taking over a neighbourhood. ${ }^{21}$ The issue of signage as a source of territorial conflict is not a new one in Canadian society as demonstrated by the language laws in Québec; nevertheless, the power of signage as an indicator of who is "within" and who is "without" is further strengthened by these recurrences. Spatial structures and indicators such as signage can strengthen or weaken social boundaries, thus accentuating social division, or, conversely, rendering the excluded group less visible. ${ }^{22}$ The decision of the mall's management to erect Chinese signage was a manifestation of the Chinese community's control over those spaces. The signs functioned as signifiers of spatial ownership of the mall by the Chinese population and as such strengthened the social boundary of the Chinese as a new demographic majority in the suburb. This switch in spatial ownership signalled the possibility of a Chinese economic and political presence in Markham, which threatened the established anglo-cultural/linguistic structure of the neighbourhood. Canadian

\footnotetext{
${ }^{21}$ Anisef 410.

${ }^{22}$ Sibley 113.
} 
societal values promote expressions of ethnic cultures as long as they are open and accessible to all. ${ }^{23}$ Ethnic enclaves are also held to this standard. It is perhaps within this context that the tensions in Markham arose.

${ }^{23}$ Mohammad Qadeer, Ethnic Malls and Plazas: Chinese Commercial Developments in Scarborough, Ontario (Toronto: Joint Centre of Excellence for Research on Immigration and Settlement, 1998) 12. 


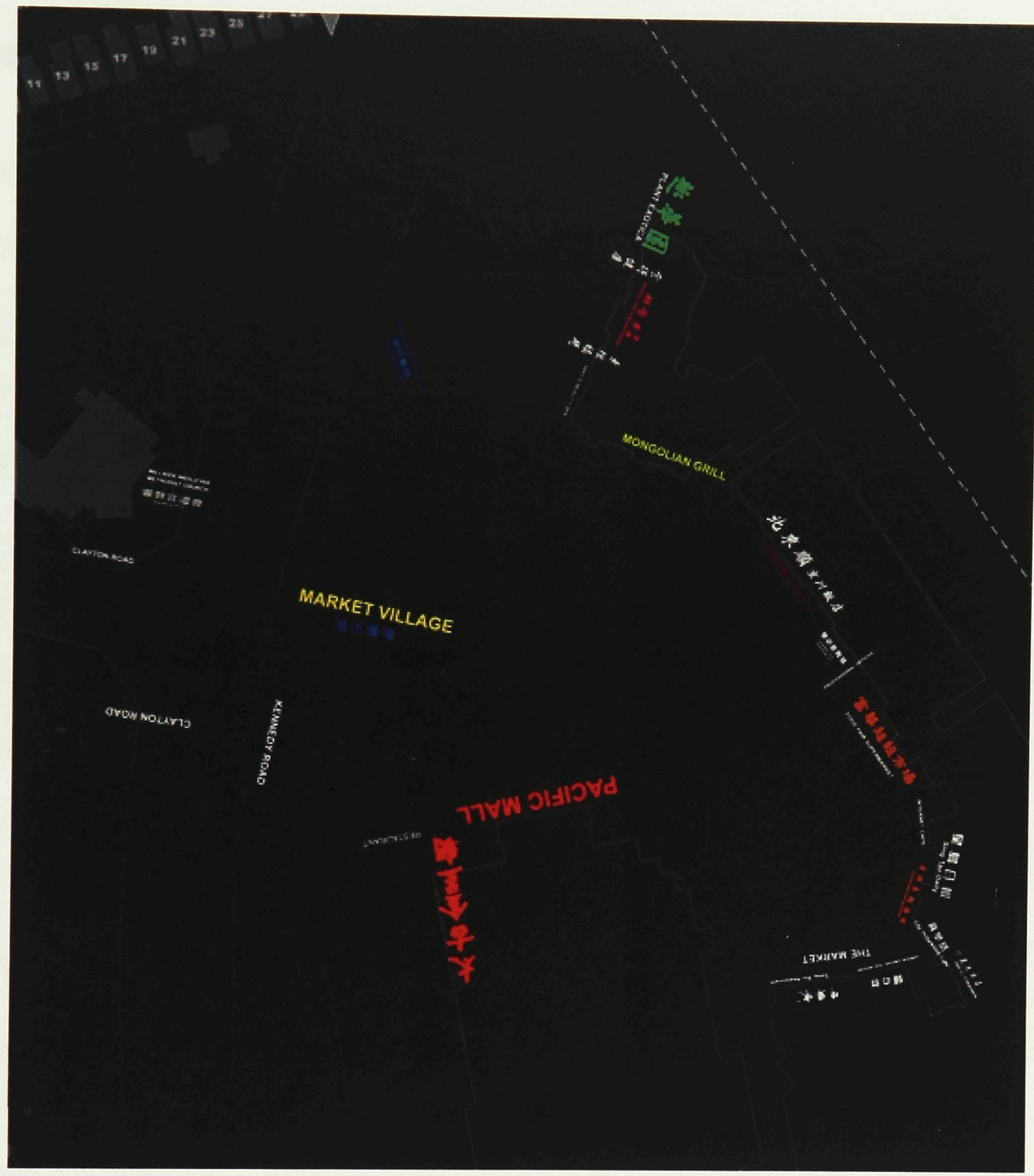

Figure 10: Signage size, language and location study of Market Village and Pacific Mall complex, Markham, Ontario. This study is inspired by Robert Venturi and Denise Scott Brown's study of the Las Vegas strip in their 1972 publication "Learning From Las Vegas". 


\section{PART 3 TRANSNATIONALISM, SOCIAL FIELDS, AND THE ETHNOBURB}

\subsection{Mobility of People and Goods in the Ethnoburb}

Within the field of Cultural Geography, there is an increasing interest in the transnational character of migrant communities, where immigrants, through their daily life activities, and economic and political relations, create social fields that cross national boundaries. ${ }^{24}$ Immigration has had a profound effect on the growth and development of Canada, not only in terms of providing labour, but also in creating global economic, cultural, and political networks. For example, after a century of immigration dominated by flows of people from Britain and Western Europe, changes to the immigration policy have radically changed immigration patterns and reoriented aspects of the nation's economic and cultural forces towards Asia. ${ }^{25}$

At the centre of these forces are the immigrant communities themselves and the contemporary ethnoburbs, which are the physical manifestations of the linkages between homelands and Canada's urban centres. It is the international mobility of these places, through the cross-border movement of people, ideas, and goods, that forces "mainstream" society to embrace the realization that immigrant settlements are shaped by engagement with other, often distant places. As a result, immigration must now be seen as a recursive process of connection,

\footnotetext{
${ }^{24}$ Margaret Walton-Roberts, "Transnational Geographies: Indian Immigration to Canada." The Canadian Geographer 47.3 (2003) 237.

${ }^{25}$ Walton-Roberts 236.
} 
including frequent travelling to homelands, and social and cultural connections by way of international telecommunications technologies and media. Immigration is not simply a single linear and permanent movement from country of origin to country of settlement, as regarded in the past. ${ }^{26}$ Another issue challenged by the international mobility of migrants is the concept of the indivisible duality of society and social citizenship. Society and societal membership in the context of Western ideology is, undeniably, interconnected with the concept of "nation state" and its clear territorial boundaries. The transnational migrant who concurrently exists in their country of origin, their host country, and the diasporic culture to which they belong poses a challenge to traditional Western ideas of social citizenry in which a citizen is expected to possess a singular loyalty. ${ }^{27}$ These ideas of global connection and transnationality are at the centre of the ethnic suburb's influence on the dynamics between migrant communities and their "host" societies.

The ethnic suburb has challenged the realities of immigration that once entailed a higher degree of severance from contact with countries of origin. The affluent populations of immigrants who frequently visit homelands, along with new telecommunication technologies, have facilitated an ease of communication with countries of origin. These connections have participated in the creation of global interdependence networks of goods and media that have come to alter first-world communities, and, in particular, those constituted by immigrants. Contemporary

\footnotetext{
${ }^{26}$ Walton-Roberts 236.

${ }^{27}$ Vincent Miller 2.
} 
ethnoburbs have also emerged as global economy outposts, playing active roles in the internationalized economy. ${ }^{28}$ This has been done by way of the growth of ethnic businesses that increasingly connect populations to homelands by offering familiar ethnic merchandise. The technologies of mobility have changed the physical regional scope of the contemporary citizen's social, cultural, and economic networks, expanding them to truly global proportions. Sociologist John Urry describes a "network" as a set of interconnected nodes, a system of positions that has the ability to bring home distant events, places, or people, and to overcome the friction of regional space within appropriate periods of time. This is all done by mobilizing, stabilizing, and combining peoples, actions, or events elsewhere into a stable mobile network. ${ }^{29}$ The ethnoburb functions as one of such nodes where ease of acquirement of ethnically specific services, goods, and ideas are at a critical mass and are therefore readily available to diasporic populations. As a node on the network, the ethnoburb exists as a fundamentally new type of social space, less defined in terms of its actual place in geography, and more defined by both local and global mobility. ${ }^{30}$ The ease of finding goods like fashion, electronics, foodstuffs, and, most importantly, media has made the businesses of the ethnic suburb competitive entities in local and global markets.

\footnotetext{
${ }^{28}$ Wei, Li, "Los Angeles's Chinese Ethnoburb: From Ethnic Service Center to Global Economy Outpost", Urban Geography, 29.6 (1998) 509.

${ }^{29}$ Urry, John, "Mobile Sociology," British Journal of Sociology 51.1 (2000): 192.

${ }^{30}$ Vincent Miller 1.
} 
At the centre of these transnational and economically vital communities are the ethnic malls, such as the Chinese malls of Markham, Ontario and Richmond B.C. These shopping centres are the distribution points for the goods and media that travel through the business networks connecting Canada and Asia. These centres have the opportunity to go beyond their present roles as mere distribution points of goods to become true transnational nodes, more adequately reflecting the transnational society of the ethnic suburb. This can be achieved with the inclusion of businesses catering to the frequent global travel of ethnoburb residents, which would solidify the position of the ethnoburb as a global business focus.

\subsection{Suburban Landscapes and Transnationality}

Studies on globalization and transnationality have examined a range of technologies that have aided in mitigating the effect of distance and time on communication. Advances in rapid communication and travel can carry people, information, money, and images across national societies with increased efficiencies. $^{31}$ To this list of catalysts propelling transnationality, this thesis argues that the suburban landscape, with its priorities on efficiency and mobility is likewise a feature.

${ }^{31}$ Urry (2000) 191. 
The physical qualities of the auto-scaled landscape have had an effect on the experience of civic and national spaces in the ethnoburb. The auto-based lifestyle of suburbanites has led to a clearly defined "point a to point b" (origin-todestination) view of movement within the city. This mobility of people itself transforms the experience of ethnically specific space. Frequency of international travel by the ethnoburb's "astronaut" population (aptly named for the large amount of time spent in airplanes) can be perceived as a global extension of this hyper-mobile lifestyle facilitated by transportation technologies. As a result of this mobility, coupled with the economic means to afford such travel, the social communities that a citizen may belong to are no longer bound by factors of distance or physical space.

The experience of ethnically specific environments within the city has also been put into the origin-to-destination, commuter mindset. As a result, the home, the place of worship, and the place of business-all once symbiotic elements of the urban ethnic enclaves of the past-now exist singularly and separate in the landscape. These ethnically specific endeavours now cater to a community of patrons travelling great distances from around the city to access their services, in essence forming focal points for the city-scaled diaspora. Consequently, any intervention into ethnically specific businesses or cultural institutions must take into account both the global and the local scales of mobility. Local businesses and institutions now deliver services to patrons from not only the local neighbourhood, but to patrons from the greater city region and the globe (by way 
of people travelling from distant homelands). In an attempt to create spaces appropriate for this reality of mobility in the contemporary ethnoburb, the design project of this thesis will incorporate this social and economic variable into the ethnoburb.

\subsection{Transnationality and the Ethnic Mall}

Viewing immigrant realities with a transnational lens enhances our understanding as to the specific nature of various immigration flows to Canada, contextualizing our investigations across multiple spaces as well as across various scales, from national systems of governance, to local processes of settlement. ${ }^{32}$ Seeing a local immigrant community as part of a larger global network of diaspora helps one to better comprehend their differing world views. It is with this focus on global networks that we will look at an immigrant building type: the ethnic mall, and the transnational realities that have shaped this architecturally scaled microcosm of ethnic, suburban society.

This building type owes its existence to the mobility and transnationality of the ethnoburb. Generally discounted by the planning profession as a mere result of local demographics and utility, the ethnic mall has become a barometer of the mobility and transnational attitudes of an ethnoburb population. The ethnic mall has emerged as a new genre of suburban retailing, specializing in goods and

${ }^{32}$ Walton-Roberts 237. 
services of ethnic groups (figure 11). The establishment of the ethnoburb superimposed an ethnic economy over a local mainstream economy, which was then transformed into a global economic outpost and a direct target for international capital investment, making the ethnoburb a vital area of economic activity and job opportunities. ${ }^{33}$ The proliferation of Chinese ethnic malls in suburban Toronto and Vancouver are prime examples of this international and local business relationship. Strong local demand for Chinese business coupled with large international investment from Asia has led to the construction of many of these shopping centres.

In the past, ethnically specific malls emerged over time by amalgamating separate businesses catering to one subculture. American Geographer Wei Li cites this phenomenon in the study of the Chinese ethnoburbs of Los Angeles, California. She concludes that the ethnoburb and its businesses are a reflection of the ability of highly mobile capital to set up coherent, effective outposts in global cities, like LA, from which to direct international business activities and to open new markets and international networks. ${ }^{34}$ Businesses such as finance, insurance, and real estate are mainstay industries in ethnoburb areas, but, most importantly, businesses that are dependent on global movement, such as importer/exporter, air cargo services, and freight forwarding, are experiencing the largest growth in the ethnoburb economy. With this global economic network in place linking the industries of ethnoburbia with the Asia, the foundation was laid

\footnotetext{
${ }^{33} \mathrm{Li} 512$.

${ }^{34} \operatorname{Li} 515$.
} 
for a prosperous ethnic business community. One result of this prosperity was the purpose built Chinese ethnic malls that were constructed throughout the cities of Markham and Scarborough, Ontario. 


\section{PART 4 SHOPPING AND THE OTHER: ETHNIC MALLS AND THE IDENTITY OF SUBURBIA}

\subsection{Ethnic Malls in the Lineage of Suburban Retail Geography}

For the suburbanite travelling within the sealed environment of an automobile, spontaneous, en route socialization is virtually impossible. With no points of social contact in between activities of daily life, the mixing and melding of disparate socio-economic and ethnic identities, which is seen as a vital component of healthy urban life, is unattainable. This social condition of the suburbs has led to the relocation of the public's former primary venues for socialization-the shopping street and the market square-into the enclosed and privatized space of shopping centres. As a result, ethnic, suburban malls constitute an important piece in any immigrant community's city-wide network of ethnic space (figure 12). A Chinese shopping centre combines commercial, leisure, and social functions in an ethnically specific environment with familiar goods, tastes, and sounds. ${ }^{35}$ In the highly mobile and transient setting of the ethnoburb, where fifty-eight per cent of the population moves from one house to another within five years, people do not necessarily socialize with their neighbours. Consequently, the experience of social, community space occurs increasingly in malls and restaurants after a commute in a car. ${ }^{36}$

\footnotetext{
Qadeer 7.

${ }^{36}$ Vincent Miller 8.
} 

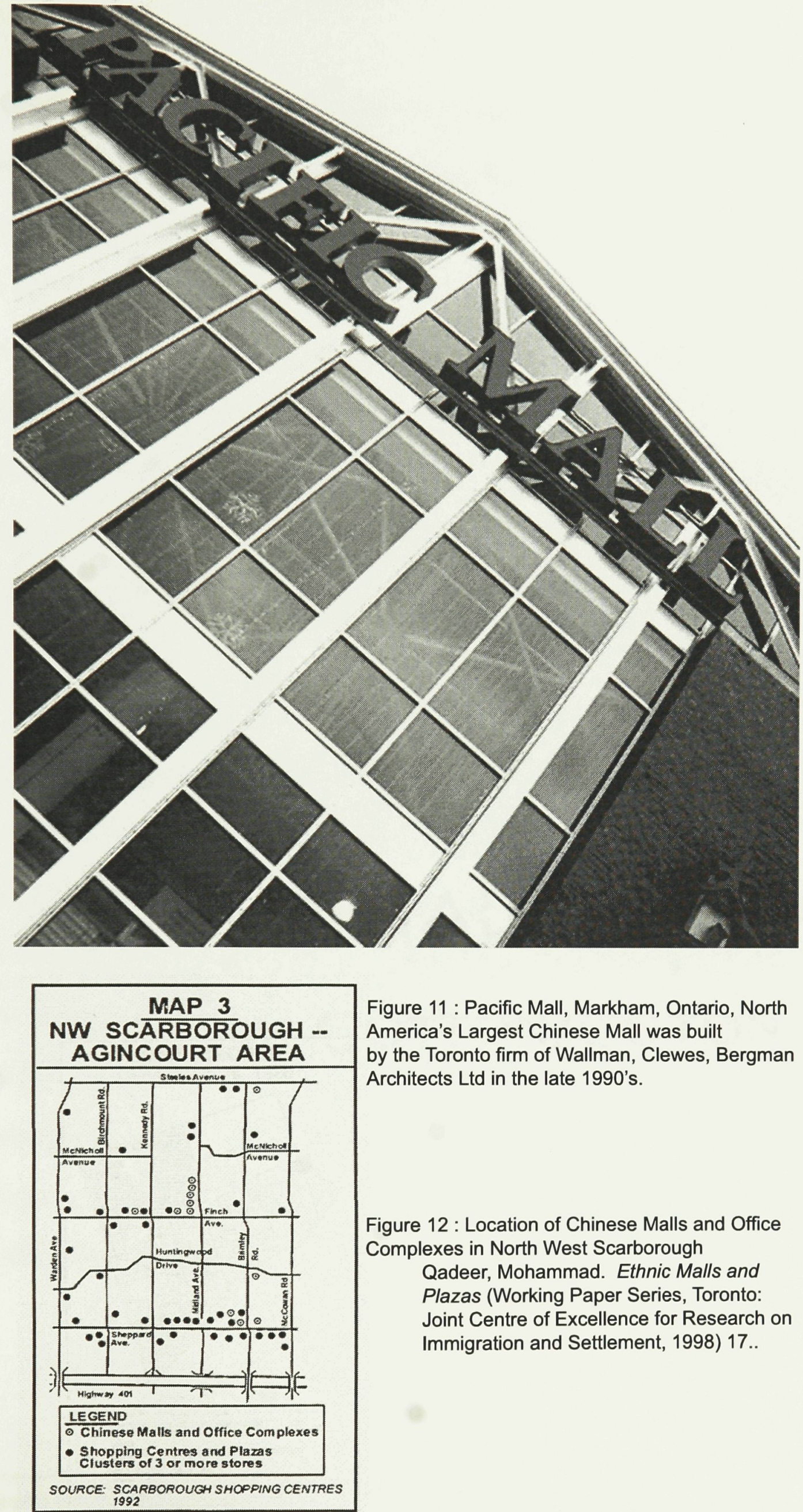

Figure 11 : Pacific Mall, Markham, Ontario, North America's Largest Chinese Mall was built by the Toronto firm of Wallman, Clewes, Bergman Architects Ltd in the late 1990's.

Figure 12 : Location of Chinese Malls and Office Complexes in North West Scarborough Qadeer, Mohammad. Ethnic Malls and Plazas (Working Paper Series, Toronto: Joint Centre of Excellence for Research on Immigration and Settlement, 1998) 17.. 
Victor Gruën, architect of the first indoor suburban mall, concerned himself with designing spaces that would replace the retail and social functions of traditional town squares and main streets that were being left behind by the automobilefuelled exodus to the suburbs. Gruën's Southdale Center in Edina, Minnesota (figures 13,14 ) became the predecessor of all enclosed shopping centres. Its internalized store entrances and multiple department store anchors became the template for all subsequent mall designs. The new suburban landscape of the post-war era presented unfamiliar challenges for architects who responded with new auto-oriented building typologies, with the mall as the premier new building form.

As a cultural outsider and European emigrant, Victor Gruën was fascinated by the new American auto-cultural evolution unfolding in the suburbs. Shopping centres were originally conceived as more than just a retail venture but as a natural descendant of the market square and as a venue for participation in modern community life. ${ }^{37}$ These centres were imagined as neighbourhood cultural and social nodes with the inclusion of theatres, community centres, and even places of worship. The idea behind this was to create not only a central gathering place filled with people during shopping hours, but also a place where one could engage in leisurely pastimes paralleling the activities of the

${ }^{37}$ Gruën and Smith, Shopping Towns USA (New York: Van Nostrand Reinhold, 1960) 24. 

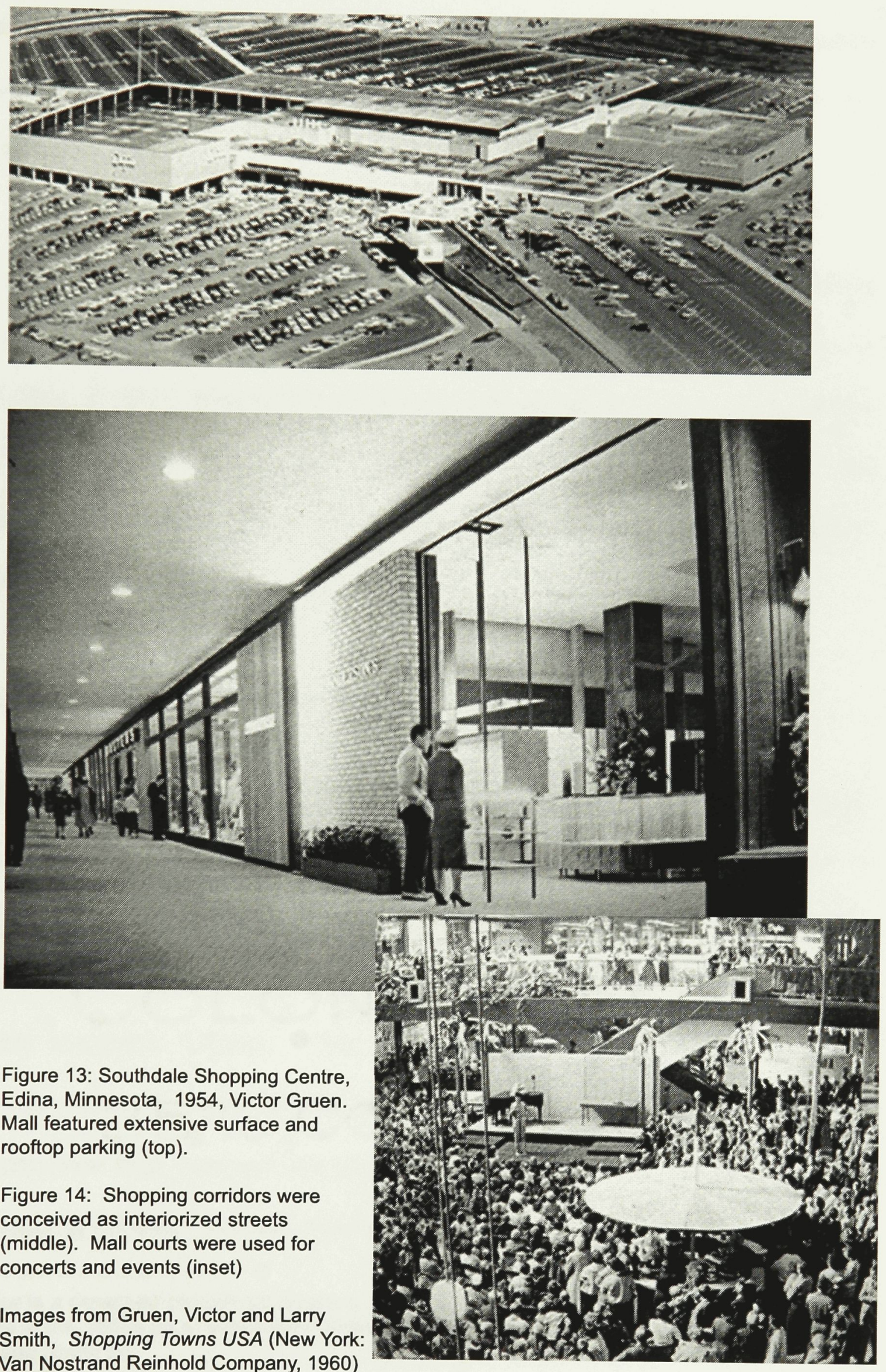

Van Nostrand Reinhold Company, 1960) 149. 
European flâneur. ${ }^{38}$ This would be achieved by making the malls accessible outside of shop hours, on Sundays and holidays, when people would window shop, promenade, relax in the garden courts, view exhibits, and patronize the restaurants. ${ }^{39}$

As the economic centres of a minority community in need of social gathering space, the Chinese malls of Markham, Ontario present an opportune site to revive Victor Gruën's ideal of the shopping mall as social space. The design project for this thesis will propose a return to community programming, such as theatres and community centres, in a suburban Chinese mall in order to make it a venue for social, as well as business life.

\subsection{Shopping and Suburban Identity}

For Victor Gruën, the shopping mall had the daunting task of acting as an "ideal substitute city" for the suburban public. ${ }^{40}$ Central to this idealized version of urbanity was the creation of a pedestrian paradise free from dangers associated with the inner city such as crime, automobile traffic, and contact with undesirable racial and economic "Others." The North American proliferation of shopping centres that culminated with the 1980 s construction of "mega malls," such as the West Edmonton Mall, had lost the social programming central to Victor Gruën's early shopping centres. Private commercial interests concerned with maximizing

\footnotetext{
${ }^{38}$ A flâneur is a detached pedestrian observer of city life, first identified by French poet Charles Baudelaire in the 1850 s as a "gentleman stroller of city streets".

${ }^{39}$ Gruën and Smith 24.

${ }^{40}$ Weisman 46.
} 
profits had taken precedence over desires of suburban city-centre building, changing the way that malls were designed and managed.

Shopping malls emerged as privately controlled and tightly guarded buildings favouring the consumer over the flâneur. In order to feel welcome, that is, avoiding the suspicion of mall security, one must look the part of a shopper. This "credit card citizenship" essentially dismantled Gruën's concept of the mall as the public and democratic space of suburbia. Unlike the pedestrian street life of Europe that Gruën hoped would be emulated within his shopping centres, the social environment of shopping centres emerged as overly and consciously managed. For one to congregate in these spaces one was required to observe bourgeois norms of social docility and conservatism in both appearance and behaviour. ${ }^{41}$ Urbanist Jane Jacob's city building canon, which states that urban vitality is dependent on disorder and diversity, has not found its replacement in Gruën's proposed artificial shopping-mall urbanity. Privately controlled malls, by virtue of their socially hermetic atmosphere, propagate the social insularity of the suburb, and, in the context of the ethnoburb, ethnic segregation, too, is further amplified.

Modern intellectual contempt for consumer society has led the professions of architecture and planning to fail to acknowledge the extent to which shopping pervades the conceptualization of the urban. ${ }^{42}$ Shopping has emerged as the

\footnotetext{
${ }^{41}$ Neil Wrigley and Michelle Lowe, Reading Retail (London: Arnold, 2002) 230.

42 John McMorrough, "City of Shopping" from Harvard Design School Guide to
} 
most common form of social engagement in the age of late capitalism. ${ }^{43}$ Increasingly, shopping is seen by the upper and middle classes as a form of leisure in itself. When the modern family goes to the shopping mall together on the weekend, the mall provides a form of entertainment, a structuring of time, and a site for constructing family relations of age and gender through the procurement of generation- or gender-specific goods. ${ }^{44}$ In this manner shopping and the suburban mall has a specific role to play in the discovery and refinement of suburban identity formation. By keeping prices high and by carrying culturally specific goods (whether to a white or non-white majority) the suburban mall attempts to keep out the undesirable poor and the ethnic other, further strengthening a shopper's sense of identification with his or her respective economic and racial group. ${ }^{45}$

The influence of the shopping mall on suburbanites' concepts of community and identity can be a useful force in the goal of developing more diverse suburban social fields. A desired affect of this thesis' design project is to diversify the user groups of the mall; this will be accomplished by building designated spaces for populations of area residents, such as seniors and youths, who use the mall for both social and consumer purposes. By adding these spaces, the presence of these groups in the environment of the shopping mall will be legitimized in the view of mall owners and patrons. This new presence will, it is hoped, widen the

Shopping, Ed. Rem Koolhaas, (New York: Taschen, 2001) 201.

${ }^{43}$ Daniel Miller et al. Shopping, Place and Identity (London: Routledge, 1998) 24.

${ }^{44}$ Daniel Miller 25.

${ }^{45}$ Weisman 46. 
suburbanite shopper's group of social identification, the first step in creating more diverse interaction in the suburbs.

\subsection{Post-Shoppers and the Reclamation of Commodified Space}

Sociologist John Urry has written about the concept of the "post-shopper," defined as one who plays at being a consumer, in a manner of complex, selfconscious mockery, in order to assert his/her independence from the mall developers. ${ }^{46}$ This independence is achieved by the resurgence of a new type of "indoor flaneurie" in which the least affluent suburban groups, but also the biggest users of the mall (mainly suburban teenagers and the elderly), engage in socializing, strolling, and other non-consumerist activities deemed as "loitering." For them, the retail spaces of the mall are not necessarily used for the developer's intended economic purposes. Both groups see the mall as a comfortable place to linger and people-watch; by this act, they are subverting the ambitions of the mall developers by asserting their right to public space apart from consuming. For suburban teenagers-too old to stay at home and too young to go to bars-the shopping centre has become the only "public" places in which to congregate. Instead of growing up to be streetwise, these suburban children learn to be "mallwise," adjusting to the subtleties of a large scale, controlled, artificial environment, and learning the lessons of materialism that will shape their human identities and social aspirations. ${ }^{47}$

\footnotetext{
${ }^{46}$ Urry, John, The Tourist Gaze (London: Sage, 2002) 151.

${ }^{47}$ Weisman 45.
} 
Nevertheless, there have been advancements in mall management's realization of the possible non-consumerist uses of the mall. The sheltered, flat, mall terrain is ideal for walking, and all across North America seniors' mall walkers' clubs have formed. But this advancement in publicness does not change the fact that malls restrict attempts to use their open spaces for political or religious purposes. ${ }^{48}$ Those attempting to do such things as protest or distribute flyers are severely restricted, and those infringing upon the rules are subject to eviction, attesting to the fact that the rights of citizenship that one enjoys in the public streets and squares of the city have not been transferred to the interiorized and privatized passageways of the suburban shopping mall.

The "post-shopper" demographic of seniors and youths will be the two main user groups of this thesis' intervention into a suburban Chinese mall. The design will propose designated social gathering space on the site of the mall that is independent from the control of mall management. This will provide much needed areas in which activities labelled as loitering may take place without impediment.

${ }^{48}$ Daniel Miller 74. 


\subsection{Artificial Urbanity and the Shopping Centre}

In many cases, mall designers have attempted to replicate the visual excitement of urban settings. Ironically, the suburban mall, seen as the antithesis of traditional urbanity has adapted an architectural iconography derived from urbanism employing a sequence of landmarks that characterize the medieval hill town, such as the defensive wall enclosure, monumental gateways, sheltered internal streets, and node piazzas punctuated with fountains. ${ }^{49}$ This analogy can be expanded: both the medieval town and the mall are concerned with defending "safe, sheltered space" within their outer walls, which are only accessed through designated, highly visible access points. The borrowing of these forms is in keeping with the desires of the mall to incorporate more of the life, and the image, of urbanity inside its walls. Maurice Sunderland's West Edmonton Mall (figures $15,16,17)$, credited as the largest mall in the world, is an extreme example of the shopping centre's appropriation of the city's urbanity. Occupying a 110-acre site, the 5200000 square-foot mall contains over 600 stores, employs 18000 people, and disproportionately contains twenty-three per cent of the city of Edmonton's retail space. ${ }^{50}$ The centre's desire to attract consumers with an idealized alternative to traditional city centre shopping has led to the ironic replication of three faux urban street scenes, of New Orleans, Paris, and a

\footnotetext{
${ }^{49}$ Weisman 46.

${ }^{50}$ Hopkins, Jeffrey (1990): West Edmonton Mall: Landscape of Myths and Elsewhereness.

Canadian Geographer, 34, 2-17.
} 

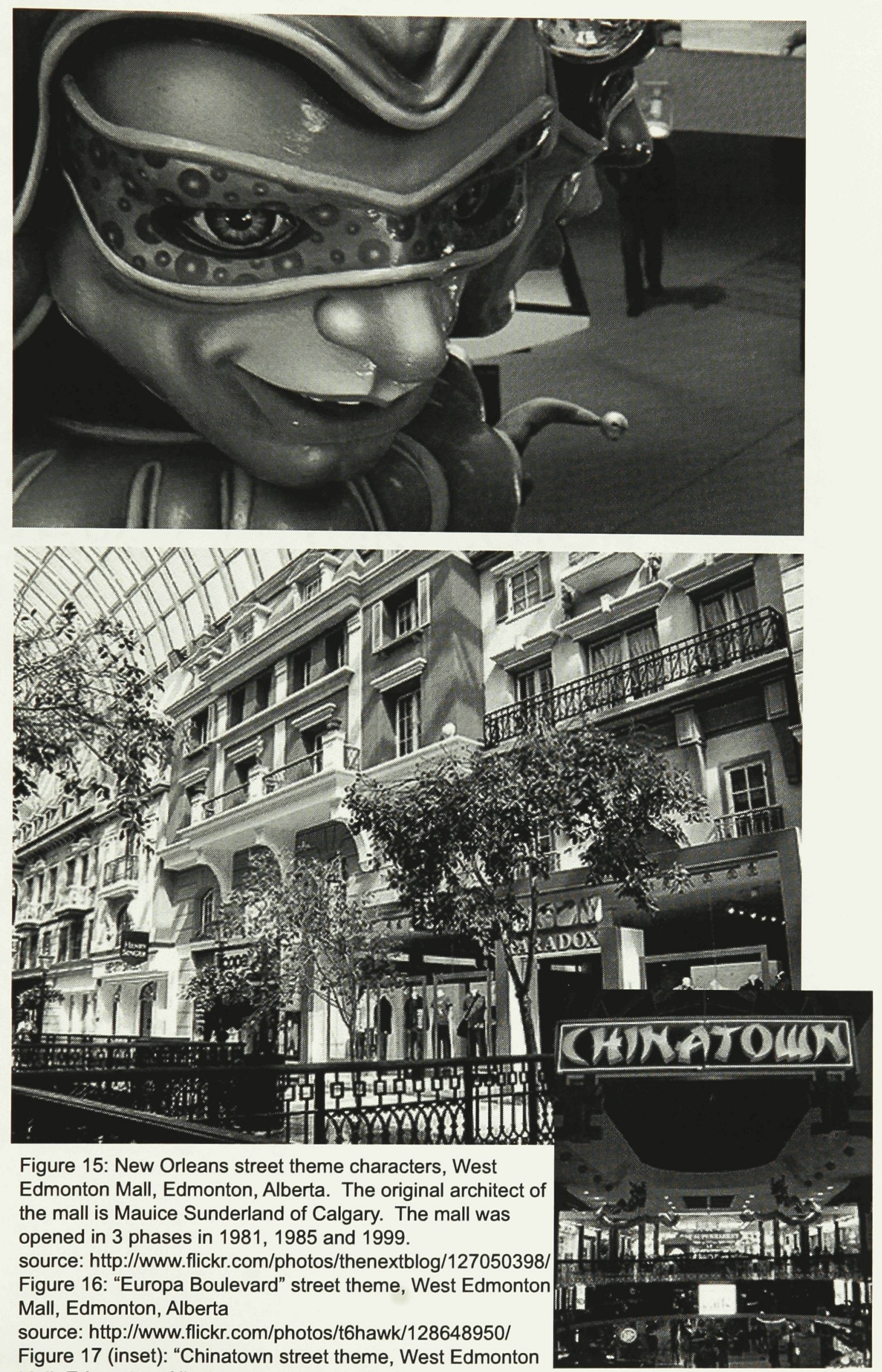
Mall, Edmonton, Alberta

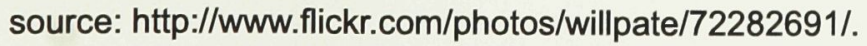


generic Chinatown, into the interior decoration described by geographer Jeffrey Hopkins:

The lively street life of cities, although excluded from the West Edmonton Mall by a strictly enforced code of behaviour, is not wholly absent. Rather; it is vicariously acknowledged, at a nostalgic distance, by the street's collection of mannequins, 'depicting the street people of New Orleans'. Frozen in permanent poses of abandon, drunks, prostitutes and panhandlers act out transgressions forbidden in the mall's simulated city. ${ }^{51}$

This is an example of the mall's desire to become an artificial and, most importantly, a social idealization of the city. The mall represents the culmination of the suburban desire to create an idealized environment free from the fears and inconveniences of downtown. The ethnic mall subscribes to similar ideals and, as such, markets itself as a more convenient and safer alternative to Chinatown or little Italy, complete with replicated ethnic streetscapes and theme decoration.

The goal of this project is to bring a social, not just a visual, replication of an urban setting to the suburban mall. The vitality of urban centres such as Paris or New Orleans that shopping centres such as the West Edmonton Mall seek to replicate is highly dependant on demographic diversity. By including programming that is conducive to a more complete form of demographic diversity, the suburban mall urbanity will function less as a purely retinal experience and more as a social one.

\footnotetext{
${ }^{51}$ Neil Wrigley and Michelle Lowe, Reading Retail: A Geographical Perspective on Retailing and Consumption Spaces (London: Arnold, 2002) 182.
} 


\subsection{Ethnic Malls and Futures in Ethnoburbia (Why undertake this design project?)}

Suburban cities lack the tradition of accommodating diversity. Even as the mass centres of many immigrant communities, such as the Jewish, Italian, and Chinese communities in Toronto have shifted to the suburbs, it is telling that these communities continue to celebrate their national holidays, religious festivals, and/or soccer triumphs on the streets and civic squares of the old core city of Toronto. ${ }^{52}$

The cause for this phenomenon lies in the fact that the suburban form of these cities, with their basic lack of spaces for collective gathering, provide few public, non-consumer spaces in which communities can express collective identity, solidarity, and citizenship. The suburban ethnic mall is the most logical point of intervention to attempt to remedy the problem of deficient public social space. Interventions may have the ability to restore the symbiotic relationship between public social spaces and private businesses, a relationship that existed in older urban neighbourhoods.

The recent exponential growth in consumer preference for big box retailing over the typical mainstream suburban mall has created a shift in paradigm away from the dominance of shopping malls in the suburban retail geography. This

\footnotetext{
${ }^{52}$ Myer Siemiatycki and Engin Isin, "Immigration, Diversity and Urban Citizenship in Toronto," Canadian Journal of Regional Science 22.1 .2 (1997): 99
} 
competitive threat gives the suburban mall the opportunity to reinvent itself in alignment with the present needs of its non-consumer as well as consumer communities with the inclusion of social space akin to that of Gruën's early shopping centres. The reason for the perceived failure of the shopping mall is that they are "lifeless, homogenous; too controlled to mesh in with the memories, the dreams and ghosts which fill real public spaces." ${ }^{53}$ By reducing the suburban citizen's varied roles to only that of consumer, the suburban mall has grossly underestimated the complexities of how a person might actually live in relation to local and, in the case of the ethnoburb, global social fields. It is the reinstatement of the perception of a plural identity of the mall patron as more than just a consumer but as a social world/local citizen that should be a main theme in the redevelopment of mall space if they are to be true, or at least significant, centres for suburbia.

The specific case of the Chinese ethnic shopping centre differs from its mainstream counterpart in that it retains some aspects of Victor Gruën's ideas of mall as community centre. This is achieved by its position as a default gathering point for a city's ethnic Chinese population. As centrepieces of suburban developments, these shopping centres are an important aspect of a neighbourhood's physical and social infrastructure. This status plays an important part in the ethnoburb's pursuit of appropriate and accessible public

${ }^{53}$ Daniel Miller 76. 
space. For this reason, this thesis will propose an intervention on Market Village Shopping Centre in the Chinese ethnoburb of Markham, Ontario. 


\section{PART 5 DESIGN PROJECT}

\subsection{Site: Market Village Shopping Centre, Markham, Ontario, Canada}

In the specific case of the ethnic suburb, the social role of the shopping centre is amplified since the ethnic mall has the added function of being the spatial centre of a minority group. Proposed interventions to such sites would now logically include the addition of cultural and educational programs conducive to community centres into existing shopping centres. The interweaving of commercial and cultural spaces could reveal a relationship between public institutions and commercial spaces in the creation of suburban socio-cultural fields and, additionally, in the case of the ethnoburb, lines of connection with the larger, mainstream society. The site for an investigation is "Market Village Shopping Centre," (figure 18) the North Toronto mall located in the heart of the Chinese ethnoburb of Markham. The choice of this site reflects an interest in the role of the shopping mall as the venue for socialization and gathering in suburban auto-scaled communities. Located at the intersection of Steeles Avenue (a major east-west artery and border marker between the city of Toronto and its edge suburbs) and Kennedy Road, this mall is readily accessible to the automobile-driving residents of this suburban neighbourhood (figure 19). Forming the diagonal northeastern boundary of the mall property is the commuter rail line of the "GO Transit" system serving Greater Toronto, although no connections are present between the commuter railway and the mall. 

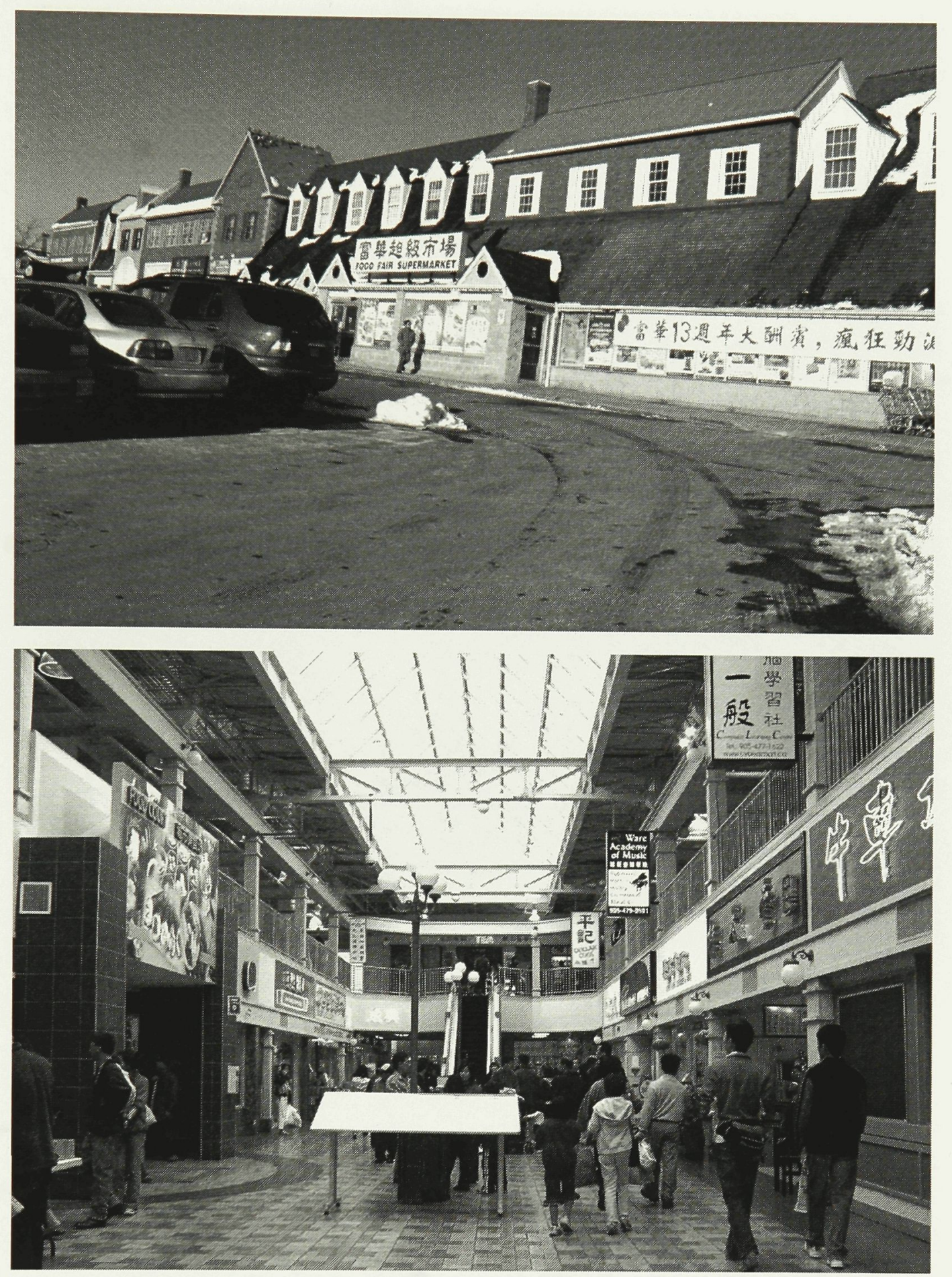

Figure 18: Market Village Shopping Centre, Markham, Ontario

Designed in a Post-modernist idiom, the Market Village Shopping Centre was created as a replica of vernacular commercial architecture of the Southern Ontario region. Exterior facades feature faux architectural detailing common to storefronts of pre-confederation towns in the area. 

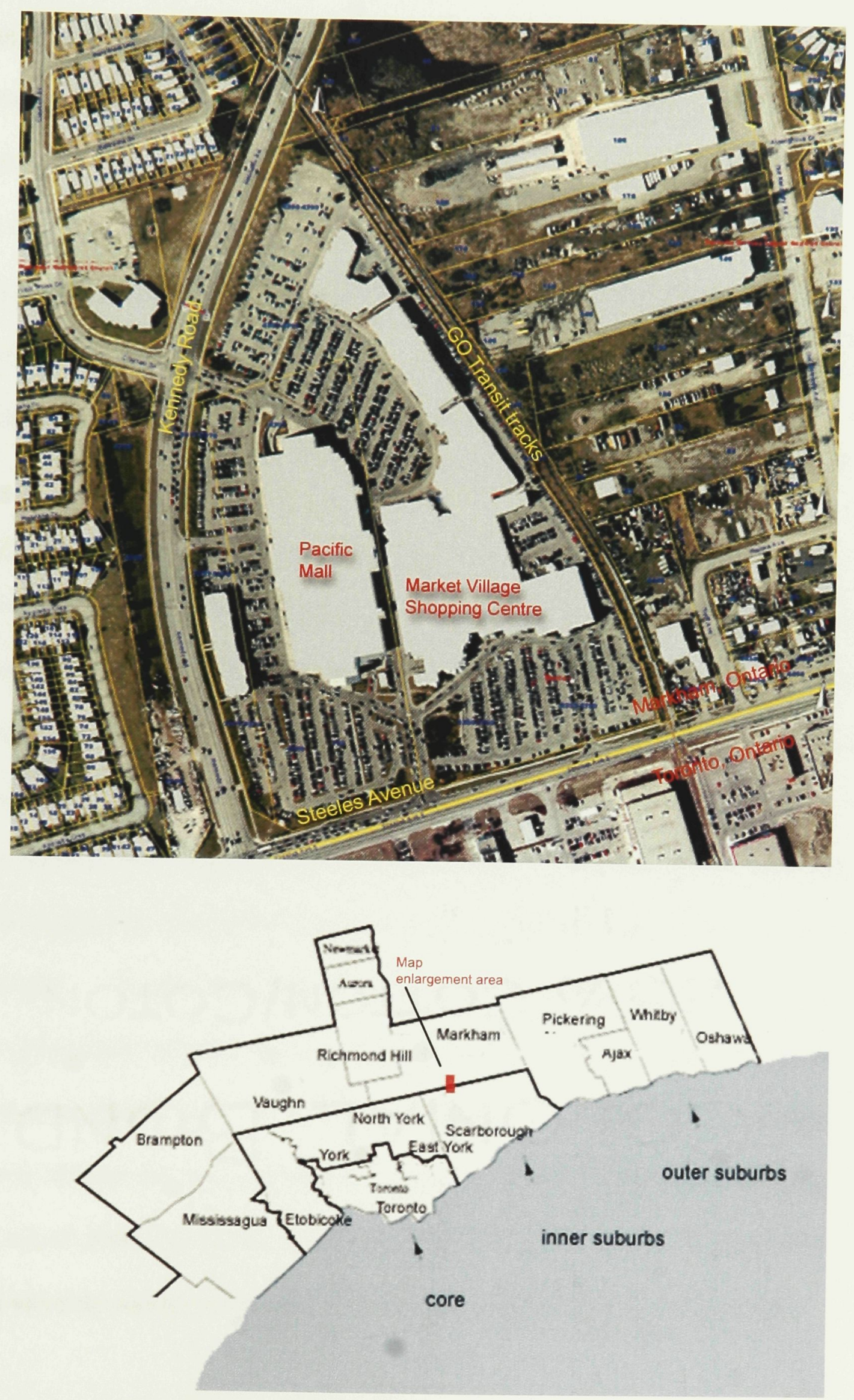

Figure 19: Site Plan of Market Village Shopping Centre and Pacific Mall Complex, Markham, Ontario 
Market Village Shopping Centre was built in the late 1980s as an open-air complex that mimicked the architecture and scale of a pre-Confederation era, southern Ontario village. The design of the "village" adapted itself to the caroriented suburban landscape by including drive up storefronts and parking lots adjacent to the complex's faux market squares. Built for the majority AngloCanadian demographic of Markham of the 1980s, goods and services offered at the shopping complex consisted of craft shops, plant nurseries, and other businesses catering to the ideal of pastoral suburban life.

In the years leading up to the transfer of Hong Kong from Britain to China, the suburban areas around the centre saw huge growth in the number of residents from Hong Kong. The Chinese population quickly grew to approximately thirty per cent of the population, from less than ten a decade prior. This rapid shift in demographics resulted in demand for goods and services catering to the Chinese community. In 1990, the Market Village Shopping Centre was bought and redeveloped by Cedarland Properties Ltd, a commercial developer, to meet these needs. These renovations included the enclosure of the complex's outdoor circulation "streets" with an industrial steel shed roof and the addition of twenty stores (figure 20). The original complex contained one hundred fifty stores and offices; the final expansion phase of Market Village was completed in 1995 at which time the centre contained 325000 square feet of space with one hundred seventy stores, making it one of North America's largest Chinese 


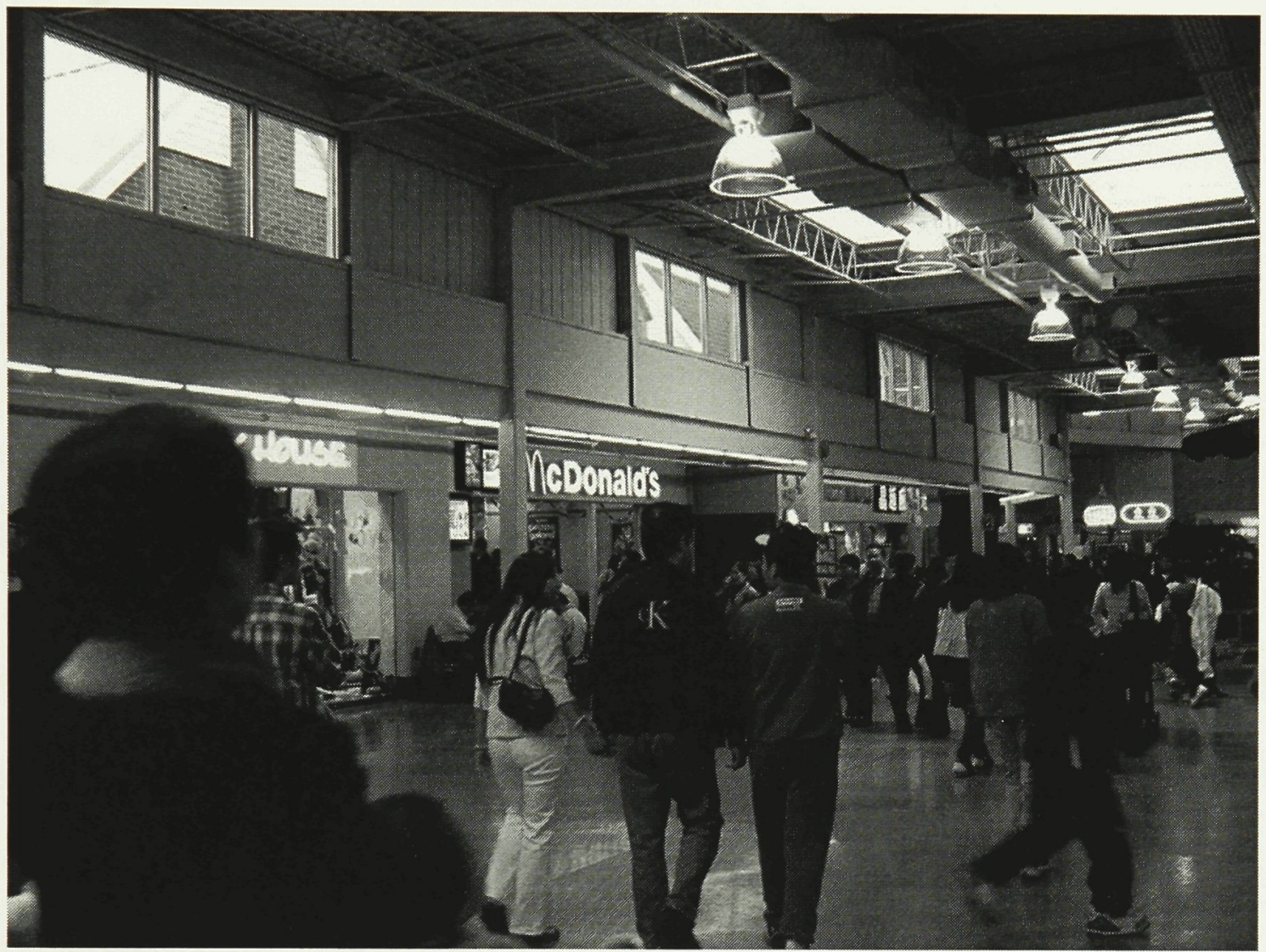

Figure 20: View of former exterior shopping street now awkwardly enclosed by industrial steel roof. Note that the brick exterior facades of the 1980's faux buildings are still visible through the clerestory windows. 
shopping centres. Pacific Mall (figure 21,22), North America's largest Chinese mall was later built by Wallman, Clewes, Bergman Architects Ltd in the late 1990s. The 270000 square-foot mall is home to four hundred stores selling everything from electronics to high-end fashion from Hong Kong. It was built adjacent to the Market Village in the late 1990s and is itself to be surpassed in size by yet another mall, which is to be built on the south side of Steeles Avenue in the near future. These three Chinese malls, along with numerous plazas and shopping centres in northern-east Scarborough and southern Markham form the core of the Chinese ethnoburb in the northeastern suburbs of Toronto.

\subsection{Design Intentions and Building Program}

This thesis project's design interventions into the Market Village Shopping Centre site attempt to address issues common to both the mainstream shopping centre and the ethnic shopping mall, mainly the lack of public spaces and space that reflects contemporary communities' socio-cultural needs. Additionally, issues related directly to the ethnic mall and the ethnoburb at large will also be addressed, particularly that of the ethnoburb's role in global socio-economic fields and the transnationality of the ethnoburb's residents. These issues have been broken down into the following categories of: publicness, mobility, transnationalism, and community reclamation of space, and will be discussed with corresponding architectural responses on the site of the Market Village complex. 

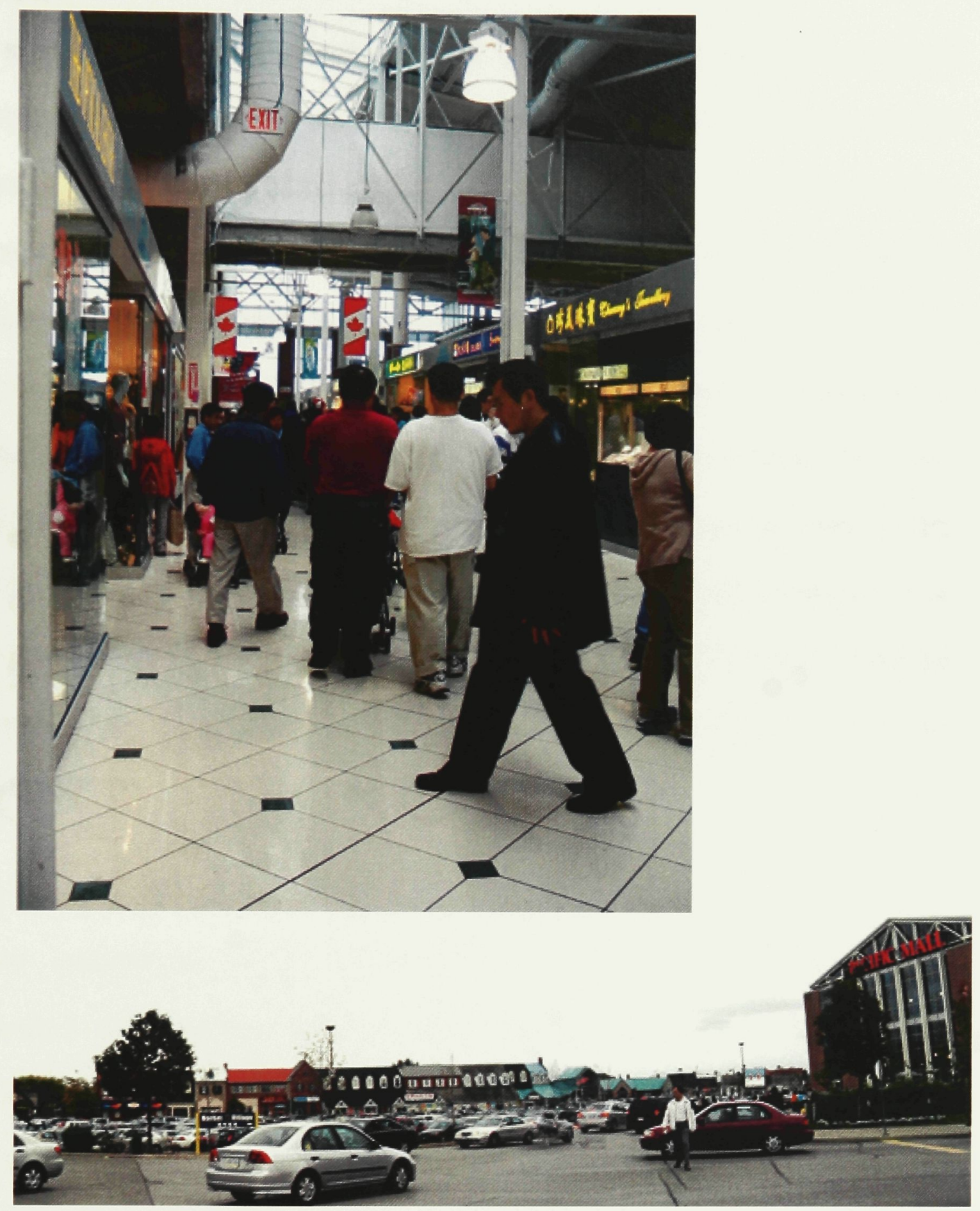

Figure 21: Interior, Pacific Mall, Markham, Ontario

The design by Wallman, Clewes, Bergman Architects Ltd for Pacific Mall was revolutionary in that the mall is comprised of very small free-standing shops with circulation pulled to the peripheries of the complex.

Figure 22: Market Village Shopping Centre and Pacific Mall exterior overview, Market Village is on the left side, Pacific Mall is on the right side. 


\section{Publicness}

Public space, which, for the sake of this project, will be defined as space accessible to the general populace that is not owned and operated for private business ventures, is not a common feature in the suburbs. There is a need for non-consumer-oriented space for gatherings and demonstrations in suburban municipalities. This deficiency is amplified within the context of the ethnoburb in which minority ethnic groups are most at need for space to demonstrate solidarity. In order to respond architecturally to this issue, the surface of the mall parking lot is transformed into outdoor public space that may be used by the community for events and celebrations as well as a daily local market. This market will be run by the local community centre and seniors' group and will represent a local exchange of goods not economically tied to the mall corporations.

\section{Mobility}

Suburban prevalence of the single-family car as the dominant form of transportation discriminates economically against those who cannot afford to own vehicles or choose not to use them. New immigrants, the elderly, and the young therefore suffer from impaired mobility when travelling to sites such as suburban malls. The mall intervention includes a large public transportation component with connections to the site's three overlapping local transportation authorities: York Region Transit, Toronto Transit Commission, and GO Transit. By making the transit entrances the most celebrated and grand spaces, this 
programmatic component reverses the site's current hierarchy of private above public transportation, in an attempt to democratize mall access.

\section{$\underline{\text { Transnationalism }}$}

In the ethnoburb, global mobility has become an extension of suburban mobility. This extremely vital global connection aims to be the ethnoburb's greatest asset as the country seeks to strengthen its ties to markets overseas. As the ethnoburb exists today, these connections are abstract, existing only in the presence of international goods and media available in the area's stores. The inclusion of provisions for international travel will crystallize the ethnic suburb's role as a hub of international economic and intellectual exchange. The proposed "park and fly" and airport shuttle bus programs, along with the in-progress international hotel, are introduced to help make the Market Village/Pacific Mall site a gateway between Canada and the Asia-Pacific region.

\section{Community Reclamation of Space}

In the highly age-segregated culture of the suburbs, semi-public spaces such as the mall are the only venues for intergenerational mixing. Current mall design does not respond to the actual social importance of shopping centres since malls are only seen as single-purpose venues for the creation of commercial revenue. Architectural responses to this issue will include designated social spaces for seniors and youths that will allow for highly visible presence of these groups in the mall. Seniors' social spaces, such as game rooms and roof gardens, will 
acknowledge the mall's role for seniors as an antidote for loneliness and isolation in which many come to the mall for people-watching, socialization, and public interaction; while space for youths, such as arcades and cafés, will provide much-needed social environment away from the academic pressures of school and the consumerist pressures of the shopping mall.

\section{Breakdown of Building Program}

- Park-and- fly

- Additional retail

- Seniors' clubs

- Youth club

- Cultural centre (classrooms, studios, meeting rooms)

- Theatre

- Travel, international business agencies

- Outdoor market

- Community roof gardens

\subsection{Design Strategy}

The design strategy will not focus on the entire proposed mall intervention but on two areas selected as the best sites to test ideas of programmatic juxtaposition of social and commercial spaces. The first site (Case One) is located in the present northwest parking lot of the Market Village Shopping Centre. The site occupies a prominent, visible position between the Market Village and Pacific Mall shopping centres. Case One will be a study of the concept of the "cultural anchor" (discussed in the next section) in which different cultural as well as retail programs are grouped together at the end of a circulation corridor in order to draw pedestrian traffic. Case Two is a study of the mall food court located in the 
centre of the complex. The mall food court will be the site of the largest programmatic juxtaposition in the design scheme. The food court is to be redesigned as a dual function space acting as both a venue for retail/food and visual/arts consumption. The purpose of this intervention is to build for a spatial symbiosis between retail and cultural space within the mall.

The addition of the above-mentioned programs attempt to use the spatial logic/techniques of mall planning itself to promote the social mixing that it formerly discouraged. The built environment forms a spatial system in which, through principles of separation and containment, spatial practices are concretely informed. ${ }^{54}$ The mall's spatial system uses highly refined circulation and layout patterns to optimize maximum pedestrian traffic and storefront visibility. Two patterns of mall planning, the "dumbbell" and the "cluster" formations, have emerged since the creation of Gruën's Southdale Center in 1954. The dumbbell plan separates the building's two largest masses with circulation along linear pathways placed between two large anchor stores. The cluster plan bundles separate building masses into groups with circulation occurring in the interstitial spaces (figure 23). Both types are dependent on the concept of the mall "retail anchor" in which large, popular stores, usually national department names, occupy positions at both ends of a corridor. This placement allows smaller tenants fronting onto the corridor to feed off the high volume of foot traffic going between each anchor tenant. This system, in effect, maximizes visibility and,

${ }^{54}$ Goss 31. 
Typical Cluster Formation

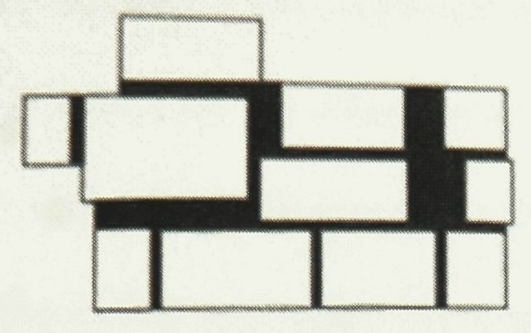

Roosevelt Field Shopping Center

1956

Long Island NY

\section{Typical Dumbbell Formation}

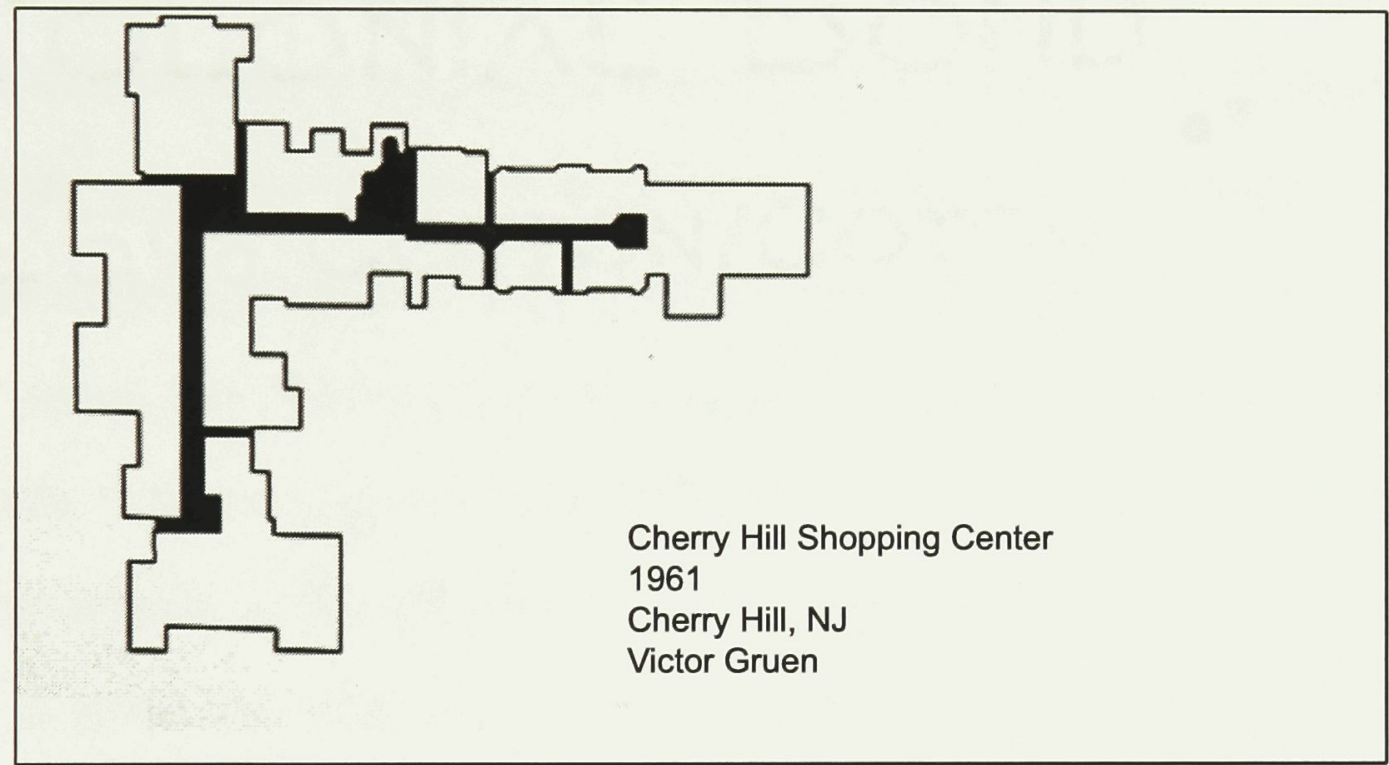

Figure 23: Mall plan types: typical cluster formation (top) with circulation between building mall masses. Typical dumbbell formation (bottom) with mall masses organized around central circulation spines with large anchor stores at each end.

Herman, Daniel, "Mall" in Harvard Design School Guide to Shopping (Cambridge, Massachusetes: Taschen, 2001) 462. 
therefore, profitability of the smaller stores. This thesis proposes the concept of the mall "cultural anchor" in which high-traffic, socio-cultural programming may replace the department store as the force of attraction moving pedestrian flow along a mall corridor. The concept of a cultural institution as an anchor of a retail area is not a new one, as attested to by the above-mentioned Queen Street East Chinatown with its Government Reform Association anchor, but, within the context of the suburban mall, the concept has not been recently explored.

The proposed intervention into the Market Village complex includes the addition of two cultural anchors that will complete the now incomplete circuit of retail anchors and corridors of the present mall (figure 24). Each anchor is conceived as a cluster of social programming, such as seniors' clubs, performance theatres, and craft markets, grouped according to the needs of identified future mall users, mainly teens and seniors, global travellers, and the city-wide Chinese community. The two anchors will contain programming related to both the global and local aspects of the ethnoburb. This is done so that programs inherently related to global networks, such as travel agencies, shipping, and banks, and programs dependent on local networks, such as produce markets, seniors' clubs, and community theatres, will be in close proximity. This adjacency attempts to re-establish the possibility of contact between groups of people engaged in 


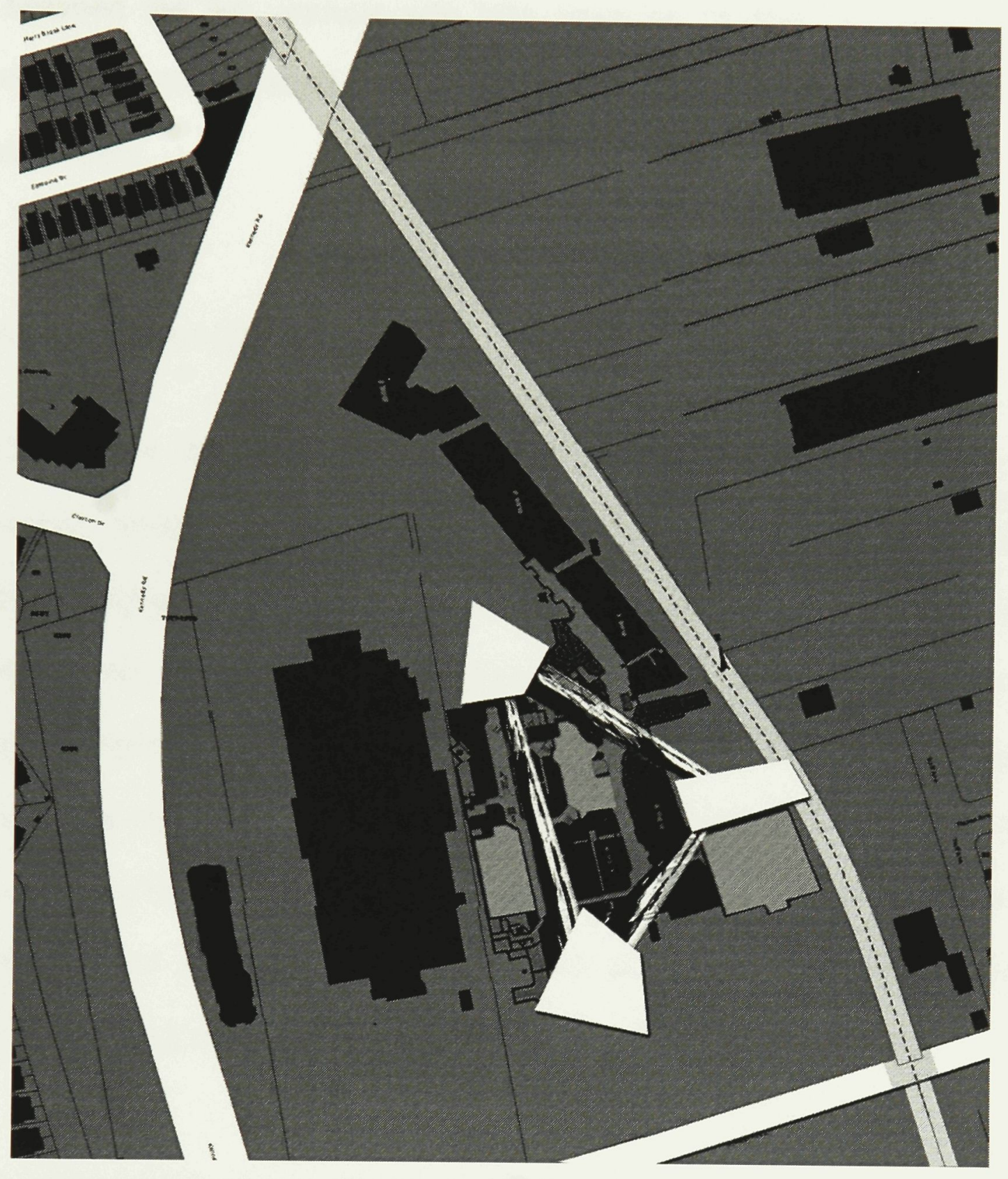

Figure 24: Study of the location of existing retail anchors and possible sites for new cultural anchors denoted in white. 
different activities, recreating some semblance of traditional urban diversity. Foot traffic between the two anchors with take place on multiple and converging corridors above the existing mall, each designed to suit the needs of its respective users.

\subsection{Cultural Anchor (Case 1)}

Case One (figure 25) deals with the design of the northwest "cultural anchor." This anchor, located in the present north parking lot, will contain "globally dependent programming" including travel agencies, park-and-fly facilities, and importer/exporter businesses. The addition of these programs is in response to the site's inherent connection to global mobility. This intervention accepts transnationality as a new cultural institution and social norm of the ethnic suburb by providing facilities for travel and international business. Additionally, "local programming" will include a seniors' club, and an outdoor local produce/craft market, responding to local needs for space to showcase area culture.

The flat public market area is conceived as an appropriate transition between the surface parking to the north and the new building. Specially designated parking spots along the edge of the market surface will be created for vendors to sell directly from their vehicles instead of from fixed market stalls. This line of vendor parking will mark a threshold between the auto-landscape of the parking lot and 


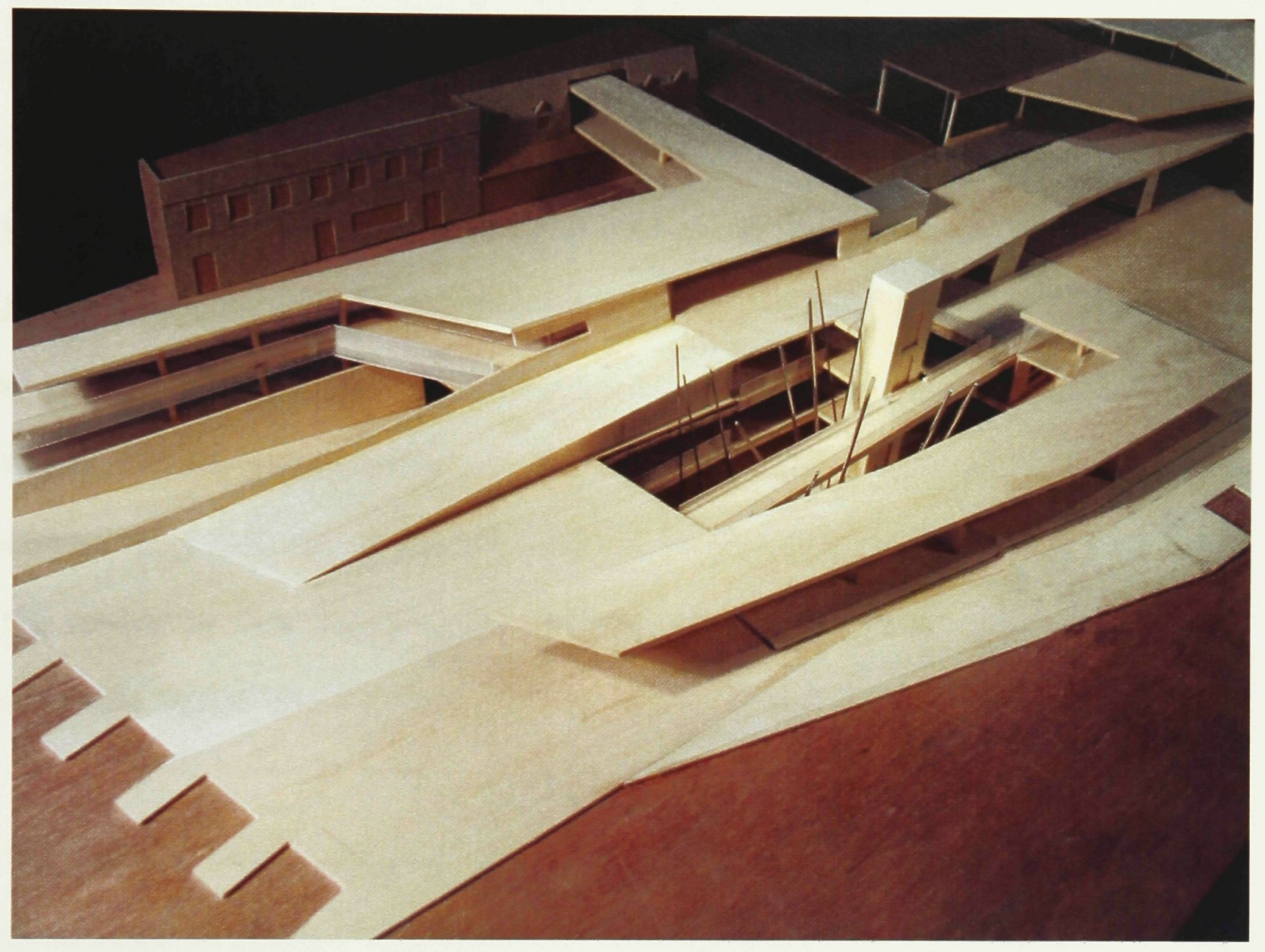

Figure 25: View of Case 1 model with drive up market stalls at the edge of the market surface. Park and fly offices bound the western (bottom/right) edge of the lightwell that allows views into the underground parking. The seniors' social club presides over the site at the top of the ramp leading to the new second floor of the shopping mall. The social club also has a bridge connection to the existing second floor offices of the mall which would also be used by the seniors' club. 
the pedestrian landscape of the mall. Forming the western edge of the market surface is a line of spaces dedicated to international businesses such as travel agencies and importer/exporter services. The presence of these businesses beside the market featuring local goods will serve to illustrate the transnational/local character of the ethnoburb shopping centre. Adjacent to the market, the park-and-fly spaces and related administration will be located on two new underground levels of parking structures. A large light well with a sunken garden will allow sunlight to penetrate to the lowest level of the parking garage, as well as affording views of the parking facility from the market square. This mutual visibility between the park and fly and the local market programs is an attempt to reveal the spatial and programmatic dichotomies between the two: The inherently local function of the market is elevated above ground, while the inherently global function of the park-and- fly is nestled into the earth. (figure 26)

The seniors' social club will be the most prominently visible feature in this composition of spaces. Located on the second level at the beginning of the new second storey circulation path, the seniors' club will feature gaming rooms, a kitchen and a large area for community events. A bridge connection will be made between existing second-floor office units and this new facility, essentially doubling both the association's space and community presence. Walls will be glazed to views from within and without, allowing mall patrons views of the club's functions inside while also allowing seniors' views to the people outside. 


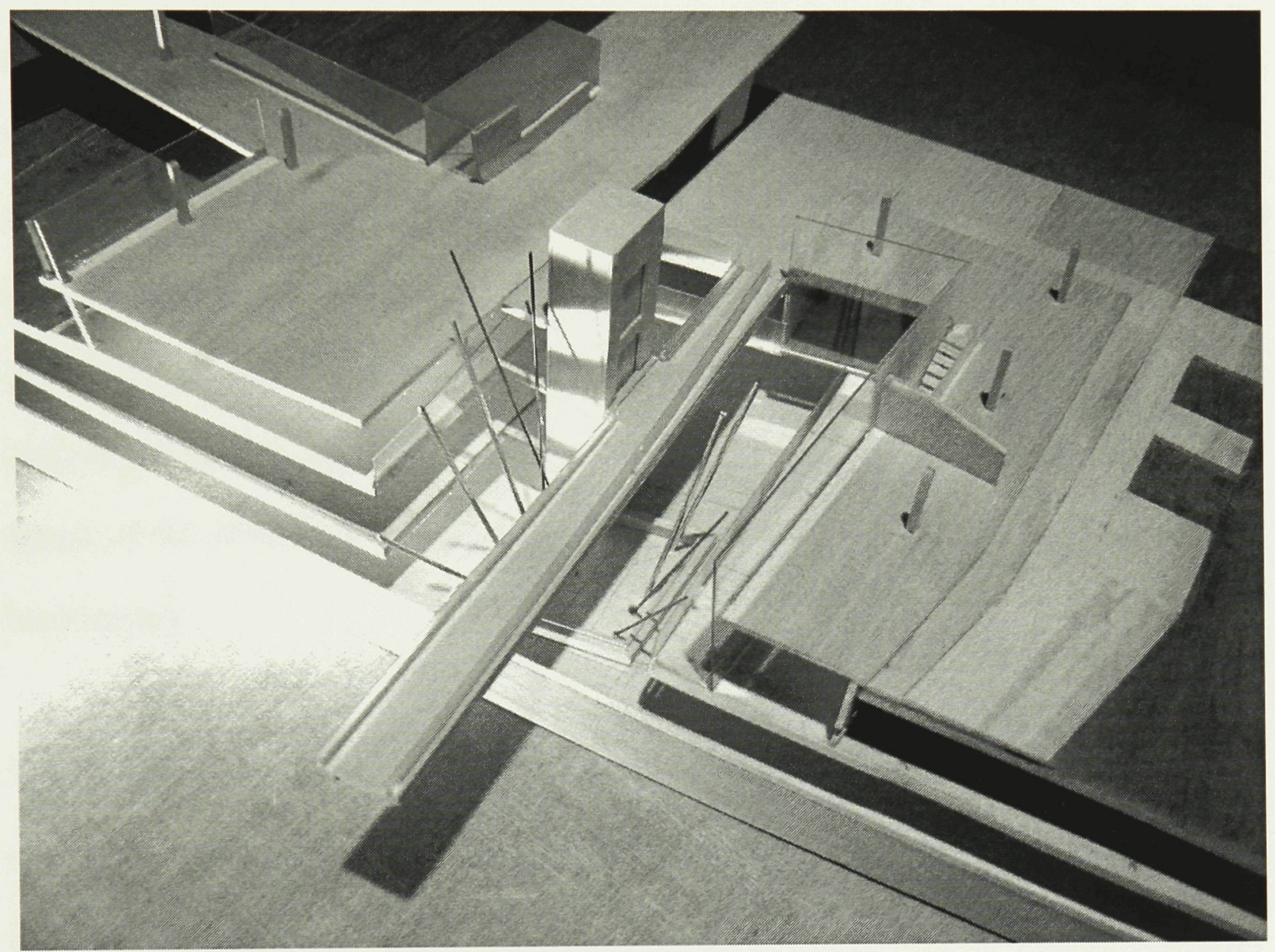

Figure 26: View of section through park and fly lightwell with garden on lowest level 
The material palette of the façades employ light steel and glass construction. This selection is meant to be a foil to the faux historicist facades of the mall. These existing facades, part of the original 1980's mall complex were constructed as a kitsch representation of local vernacular building styles with brick walls and small window openings. These facades functioned as cultural signifiers, showcasing the image of a traditional Southern-Ontario streetscape as a sign of cultural continuity between the past and present day. The glazed facades of the new intervention will also function as cultural signifiers but instead of relying on the image of the facades themselves to give evidence of sociocultural climate, it will be the view of the activities behind the facades which will speak of the site's functions, whether that is the seniors club or the transnational businesses.

The design brings into account the persisting point-a-to-point-b mentality of suburban commuters. By juxtaposing different scales of mobility-local, as represented by the commuter trains, and global, as represented by the park-andfly facilities-the two scales of connection, which are important cultural aspects of the ethnoburb, will share a common physical space to be played out and viewed. This building will be seen as a node of transference between local and international travel, where in some spaces the local commuter might, for example, have with the choice of a train ride downtown or a connecting route to Hong Kong. Additionally, the inclusion of a program for international travel will 
be a major incentive for mall developers, given their current ambition to develop a large hotel on the mall's adjacent property.

The circulation pathways that connect to the anchor will contain retail and nonretail programming along their lengths, which, at critical points, will be intersected by the path of another user group, promoting social mixing. For example, pathways between the seniors' club and the community gardens converge with pathways between the commuter train station and the parking lot at a shared coffee shop, allowing for people-watching and intergenerational mixing. This configuration is meant to juxtapose different demographic groups that would not normally mix in the setting of a suburban mall by locating cultural and commercial programs together and providing space for casual contact between varying economic, class, and age groups. The pathways will connect the new cultural anchor and the train/shuttle bus station on the upper level, creating a new second floor to the mall in which cultural spaces will predominate over retail ventures. The social spaces such as games rooms, lounges and cafes will line the length of the circulation pathways located on the roof levels of the existing mall buildings. (figure 27) Placing these social spaces above the main shopping corridors allows the shoppers below to visually interact with the "post shoppers" above, while allowing the patrons of the games rooms and other social spaces the choice of not participating in the retail activities below. 


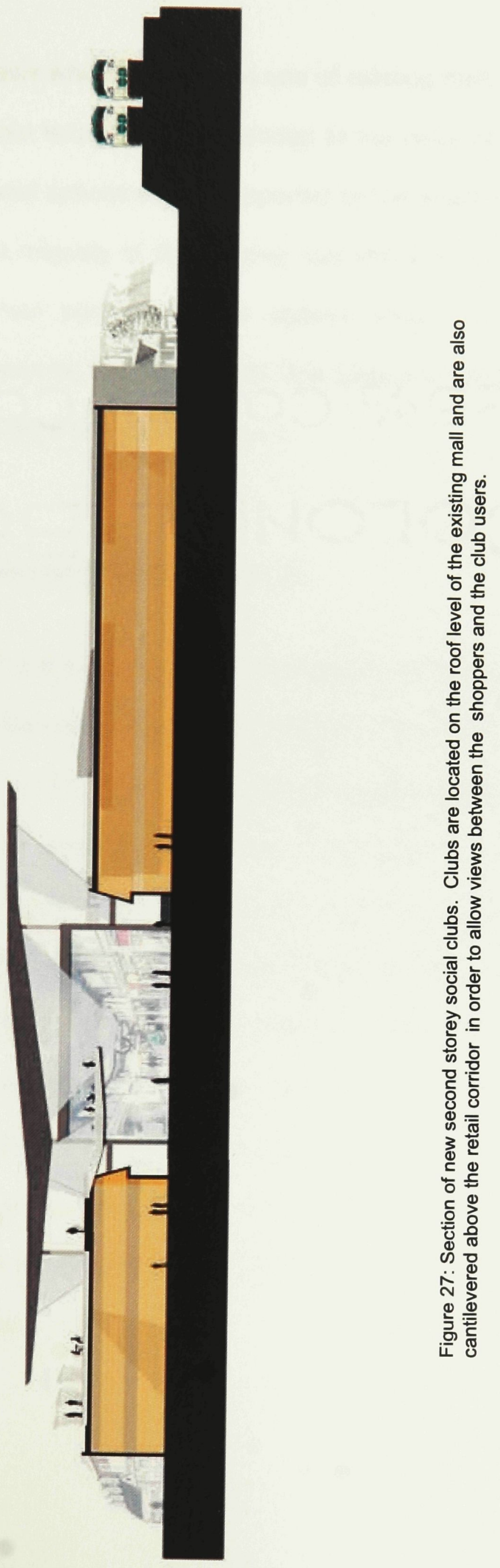


The attitude of this thesis which calls for the use of existing mall conditions such as circulation and layout techniques is extended to the issue of structure. The new second storey social spaces will be supported by the existing column grid of the corridor roof. The majority of the existing roof structure will remain except where new, higher roof portions denote spaces where social program is overlapping with commercial. (figure 28 roof) The largest of these spaces is the food court which is the area of focus for Case 2.

\subsection{Food Court / Community Theatre (Case 2)}

The food court theatre is conceived as a central gathering area where the social and retail functions of the mall are the most symbiotic. The stores on the eastern edge of the food court will be replaced with a large stage complete with support facilities in the rear. The stage has a few rows of dedicated conventional theatre seats, but the majority of the seating will happen in the reconfigured food court. The food court seating is arranged on a series of tiers allowing patrons maximum views of the stage. (figure 29) This plan provides a casual seating area where shoppers can watch performances by local arts groups, essentially increasing the community presence of these organizations. The arts groups will depend on the consumer traffic flow of the mall for their amplified community exposure, while the mall retailers will benefit from the new patrons coming to the mall to watch the performances. 


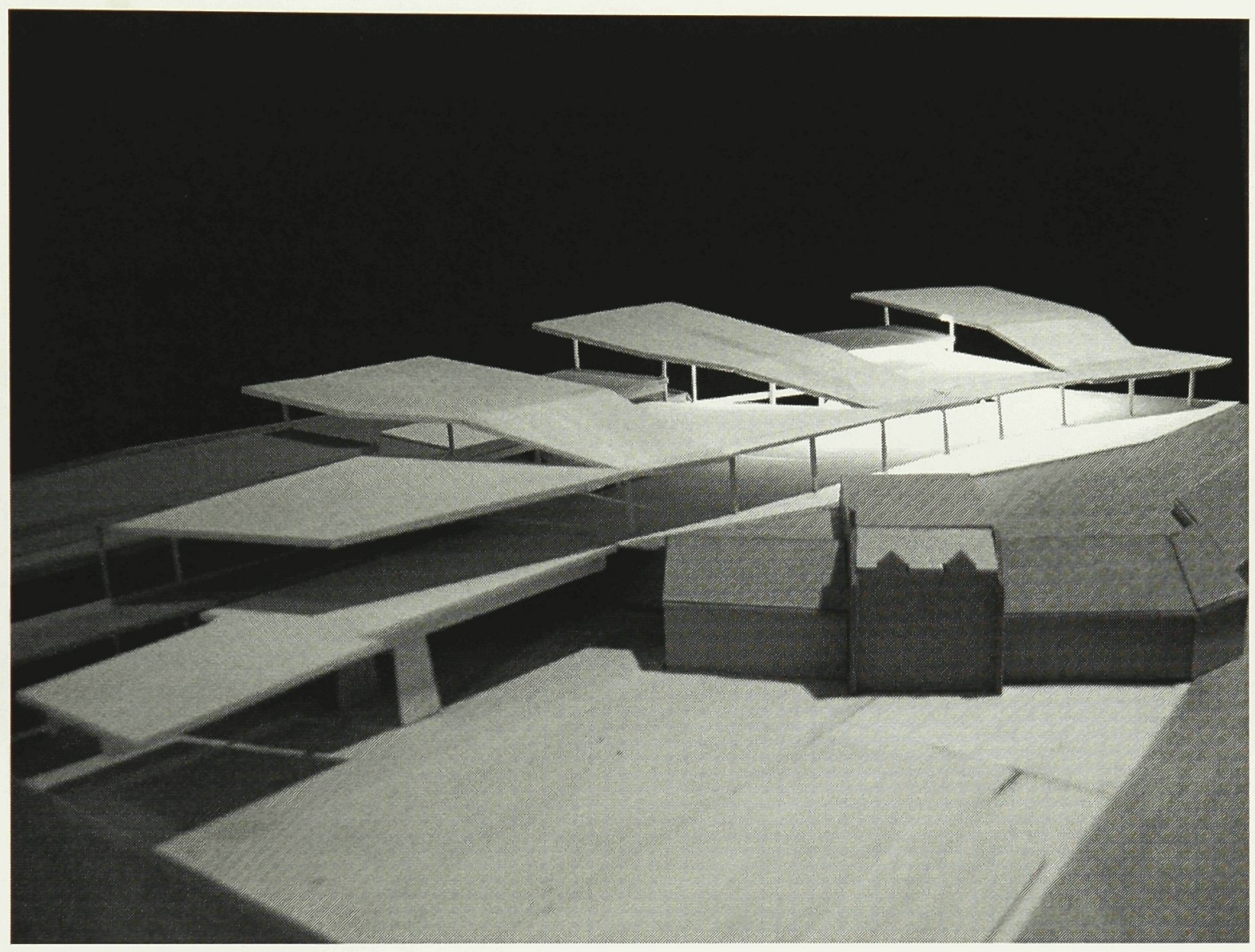

Figure 28: View of model showing new roof portions which cover spaces where social programming overlaps retail. 


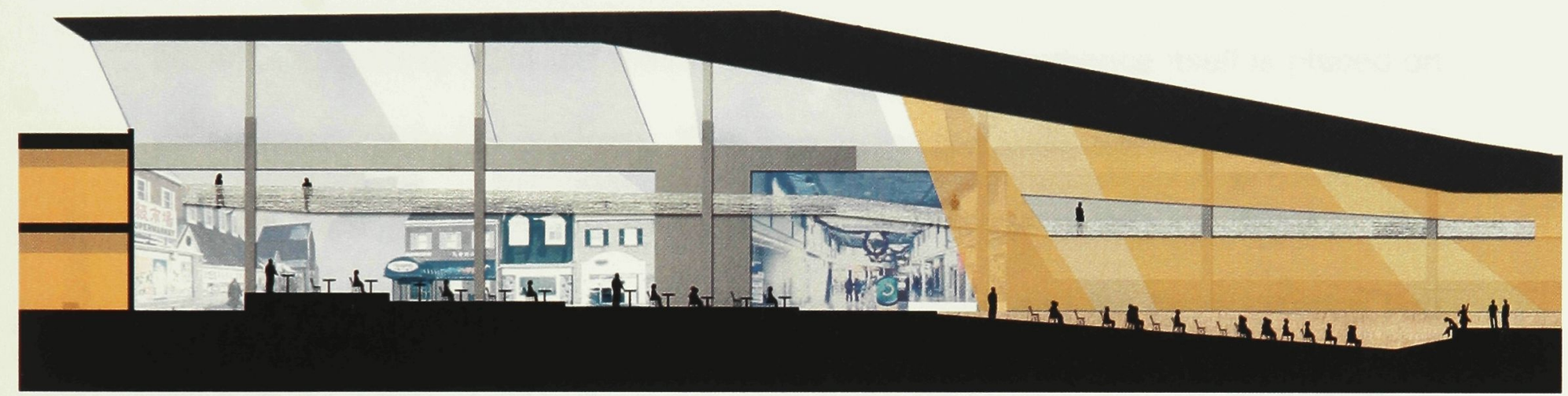

Figure 29: Close up of section showing tiered food court seating and its relationship to the theatre. 
One aspect of mall circulation is the method in which corridors are contrived to confuse the shopper in order to maximize wandering and window shopping. The new food court arrangement utilizes this mall planning principle. The pathway that crosses the food court theatre can be closed off in the event of a large formal performance; this will force mall wanderers to circulate in the periphery pathways surrounding the tiered floor seating of the food court. The effect of this arrangement is that the wanderer is put into closer proximity to the shops and stalls lining the food court theatre space. This temporal change in circulation allows stores not on the main circulation path between the new mall anchors to benefit temporarily from the mass of foot traffic. The audience itself is placed on an elevated stage-like platform. This transforms the audience itself into an object of gaze from the pathways surrounding it, putting the people on display. The circulation paths between the rooftop social spaces and the transportation hub will also be highly visible above the food court, reinforcing the mall as a space of people watching and socialization.

The food court theatre construction will employ the same sensibilities as Case One in that this area's new roof structure will use the steel column grid of the existing mall roof. The new roof will be higher than the existing one in order to accommodate the social spaces located on the roof tops of the existing adjacent buildings. These spaces will be separated from the main volume of the food court theatre by simple transparent glass railings in order not to impede views of the theatre and audiences. 
The new spaces created by Case One, Case Two and their related circulation system will act as an extension of the current mall's area. The new circulation will be interconnected with the old mall system and, at those points, will serve to revive unprofitable low-trafficked sections of the mall by bringing in additional foot traffic. The resultant composition of cultural and retail amenities creates a symbiotic relationship. Cultural ventures and retail businesses will feed off each other's flow of visitors. This benefit creates incentive for current mall owners to pursue this redevelopment while opening up the shopping centre for activities more consistent with urban public space, such as strolling, people-watching, and public gatherings in the outdoor spaces. 


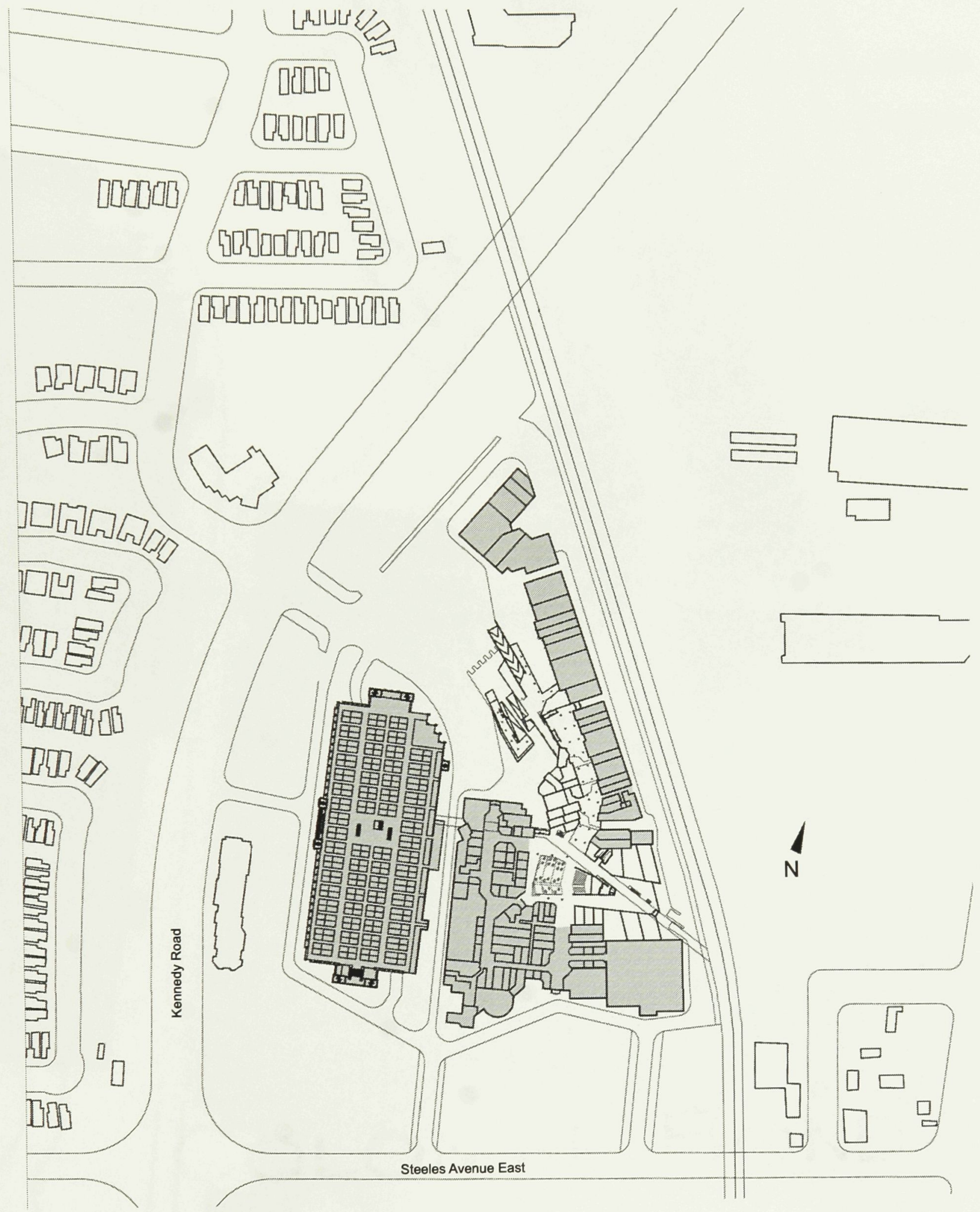

Figure 30: Pacific Mall and Market Village Site. Existing mall buildings shaded in grey 


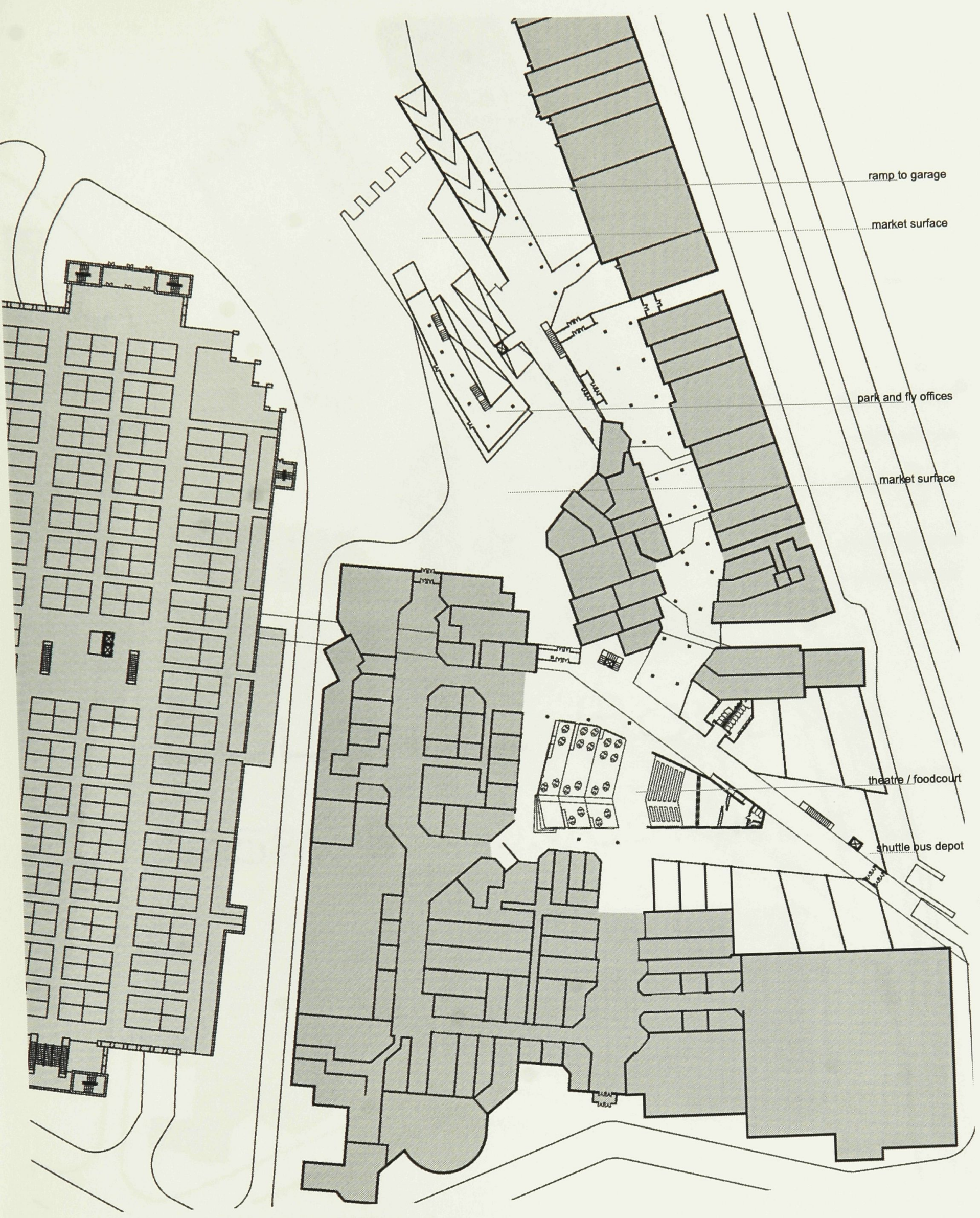

Figure 31: First Floor 


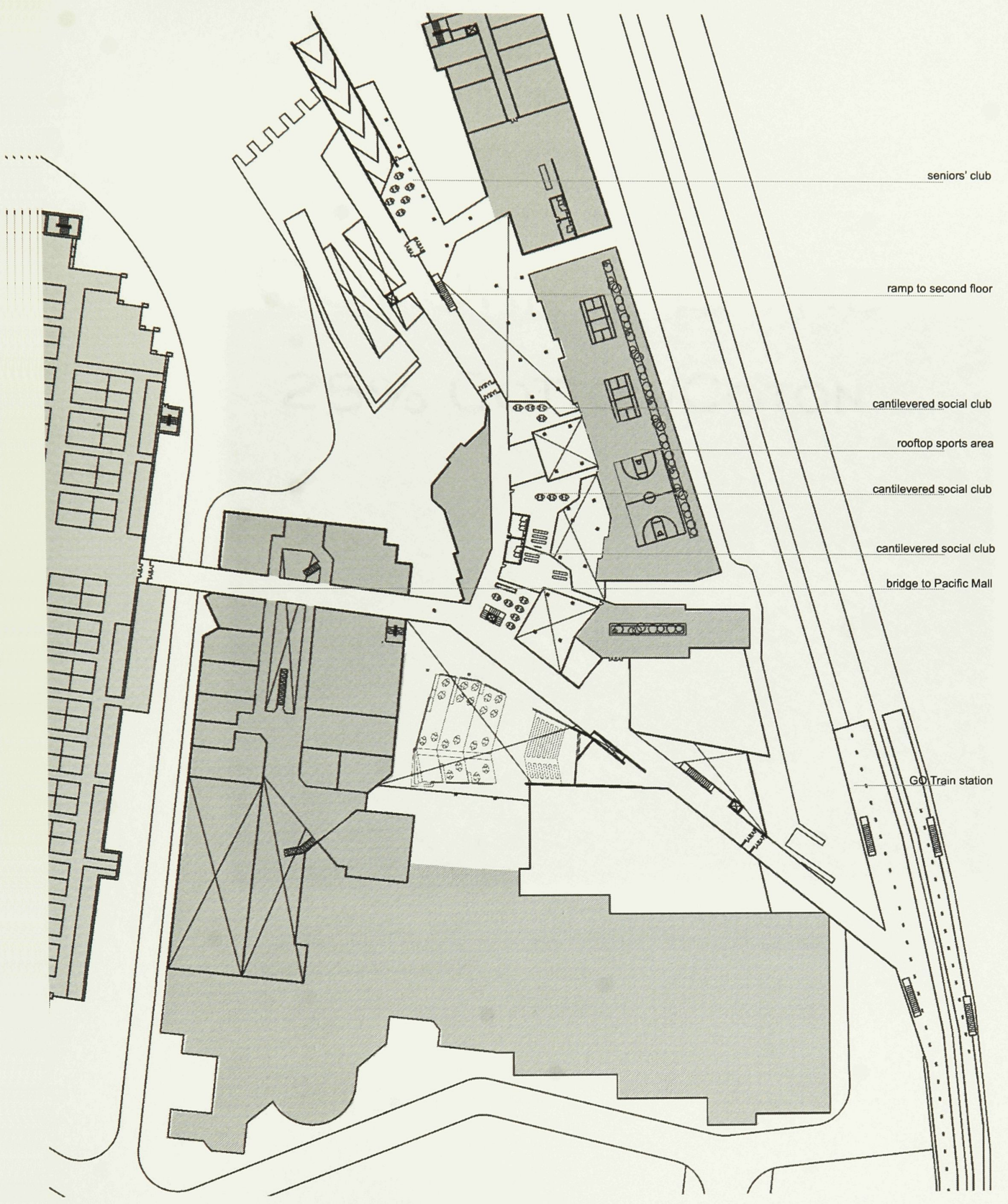

Figure 32: Second Floor 


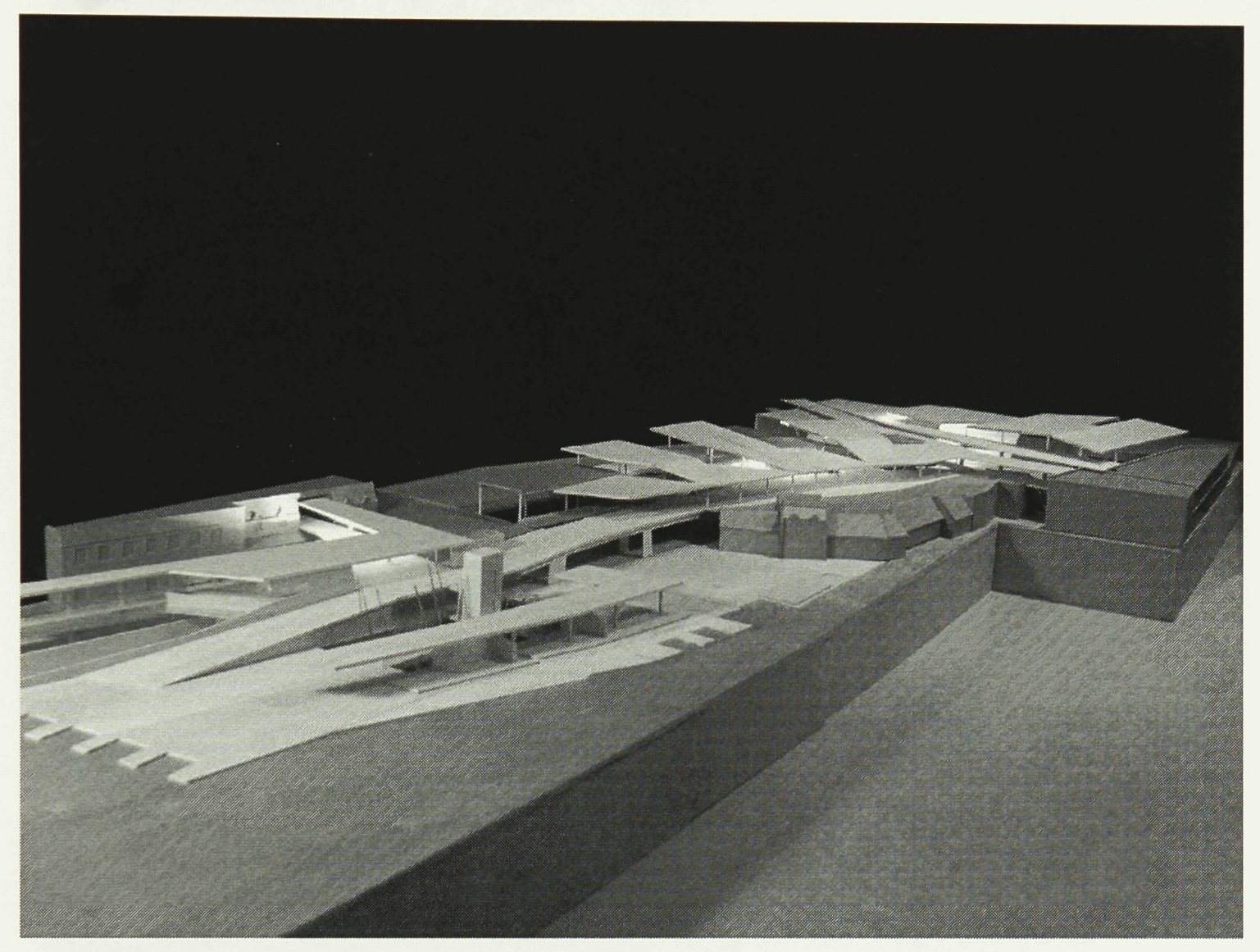

Figure 33: overall view of model showing market/park and fly in foreground and second floor roof additions in background. 


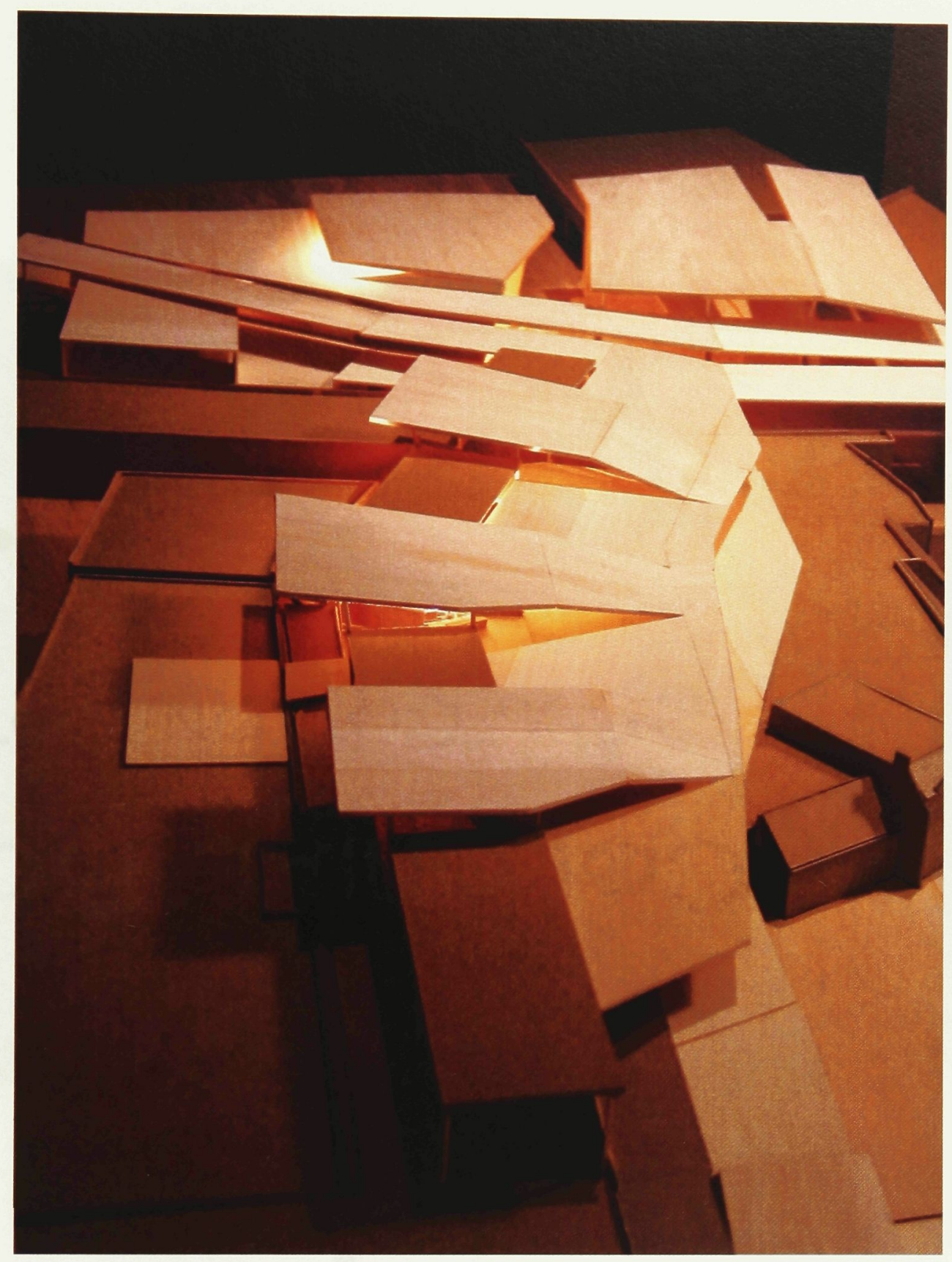

Figure 34: Overhead view of roofs of new social clubs showing how they interact with existing flat shed roof of the retail mall. 


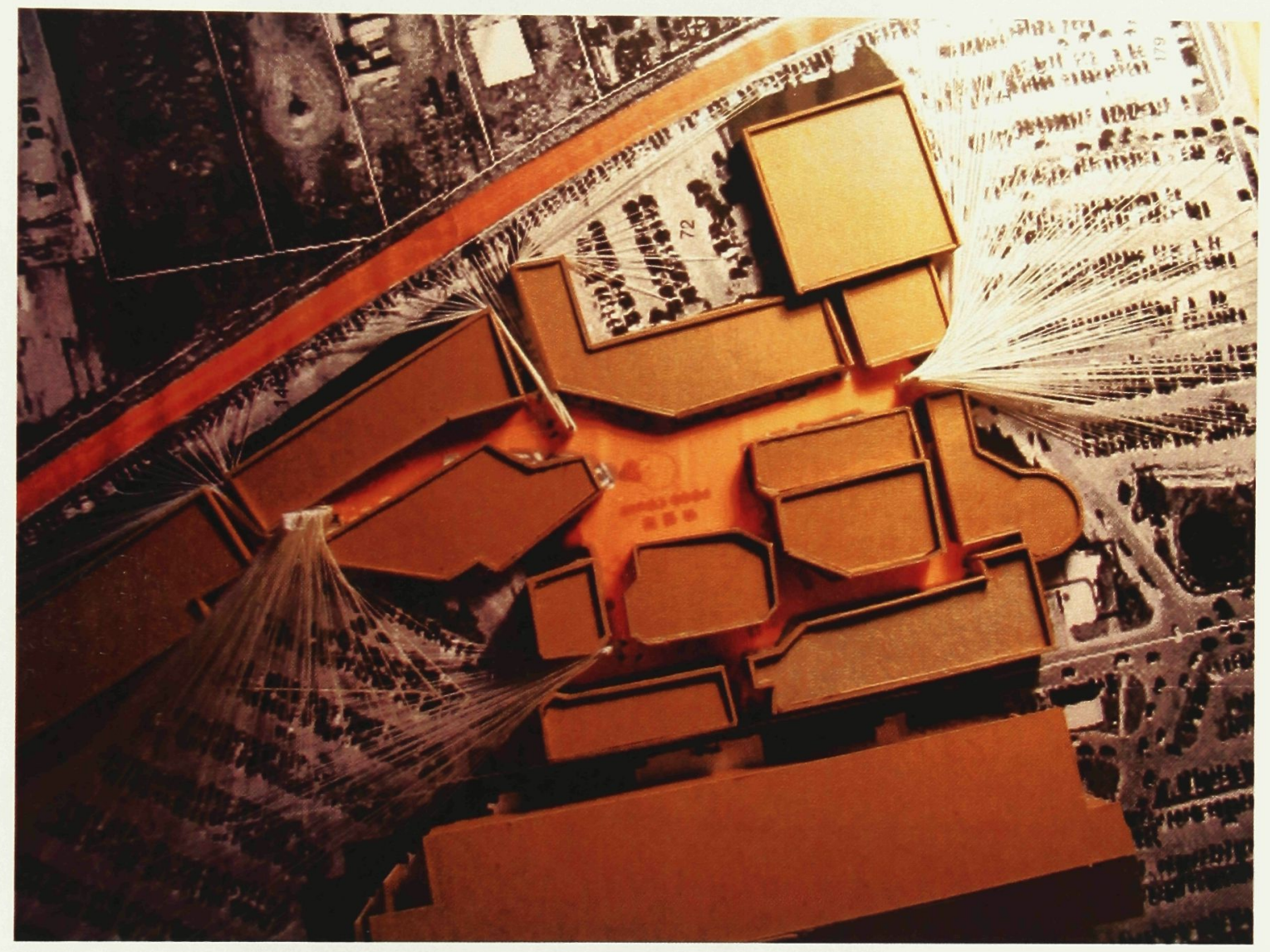

Figure 35: Process work: String diagram mapping the distance between each parking stall and the major mall entrances. Diagram helped to locate best possible location for new cultural anchors for foot traffic from patrons arriving by car. 

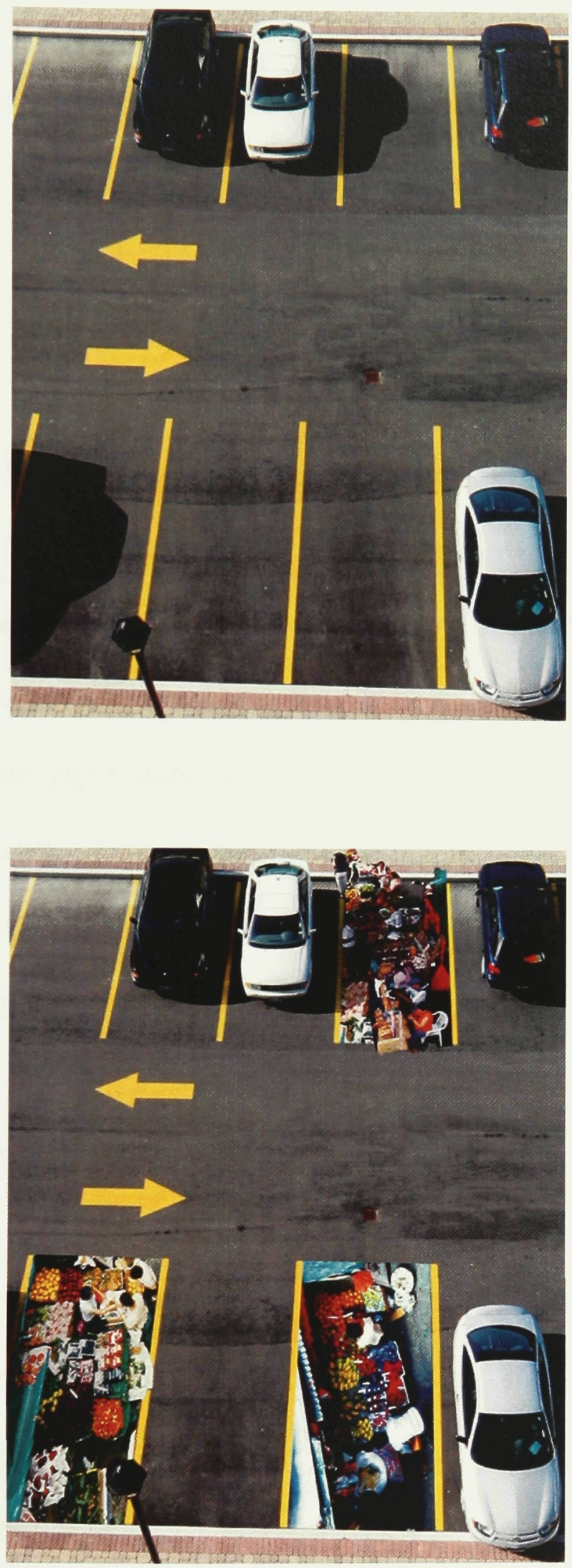

Figure 36: Process work: conceptual collage of reinhabitation of mall parking lot by local produce and crafts market 


\section{CONCLUSION}

In conclusion it is appropriate to return to the architectural responses of this thesis. The building type of the shopping mall has suffered from the suburban mentalities that favour the human detachment associated with the automobile and the consumer over the human engagement associated with the flâneur and citizen. The mall, once seen by its inventor Victor Gruën as the suburb's future social and business centre, has not achieved this idealized status. Instead, after decades of designs focused on achieving maximum profits, the suburban shopping mall has become a single-use building meant for the sole purpose of retail consumption. In the space of the conventional mall overt socialization and political awareness, let alone demonstration, is thwarted. The ethnic mall is also a product of this ideology, but, as the physical centre of suburban ethnic-minority groups, there is a great need and a great opportunity for these shopping centres to become public, community cultural and social centres. It is for this reason that the social longings of Victor Gruën's early mall schemes might find their humanistic successors in the landscape of the ethnoburb.

It is with the building type of the shopping mall that architecture can have a role in creating spaces more accessible to a wider portion of ethnoburb residents. The strategy of this project was to work with the suburban mall typology and to even employ some of its own spatial techniques in the goal of creating a more democratic and humane environment. This proposed intervention utilizes the conventional dumbbell plan formation by grouping social and cultural programs 
such as seniors' clubs and youth entertainment areas into large masses at the end of mall corridors. It is hoped that these new cultural anchors, as manifested in the proposed design, might help to direct pedestrian traffic along presently underused areas of the mall. It is this possibility of increased mall traffic that is the key to the proposed plan's appeal to mall owners, additionally restoring the symbiotic relationship between an ethnic community's businesses and its cultural institutions.

By building for programming that caters to diverse groups, architecture has the capability to negotiate the social relationships of a building's users. The addition of programs that respond to the transnational character of the ethnic suburb, such as "park and fly", and the addition of programs responding to the local need for non-retail public space for the mall's post-shopper users (such as seniors and youths), has been done in order to encourage mixing of disparate suburban demographics. In this manner, the project relied foremost on the simple act of programmatic juxtaposition to promote spatial mixing of different economic and social groups, a feature lacking in the highly economically segregated suburbs. By overlaying a network of public social programming on the current retail complex, the project has helped to widen the limits of the shopping centre's range of "legitimate" mall users. Adding spaces built for socializing on the site of the mall allows youths and seniors the opportunity to participate in the vitality of the shopping centre, without feeling the need to satisfy consumerist obligations or fuelling the suspicion of mall security. 
This architectural project as a critique of the socio-cultural climate of the ethnic suburb did encounter limitations. The success of the new cultural interventions as areas of demographic mixing is highly dependent on the flow of daily commuters through the mall. Making the mall a twenty-four hour centre for socialization would be only achieved with the addition of residential units in nearby proximity to the mall. Segregation and lack of suburban public space are foremost issues facing planners at a city scale. Nevertheless, this project, which focused on the issue in the architectural scale of the shopping centre, is affected by these same issues. The shopping centre was chosen because it is arguably the epicentre of the suburban landscape. The shopping mall, despite its primary retail character, has the ability to act as a centralizing influence to counteract sprawling development. ${ }^{55}$ This type of development could act as an important opponent to the often insular and isolating nature of suburbia by providing public spaces for suburbanites, consumers and otherwise, to interact face to face.

The suburban enclosed mall is perhaps one of the most iconic building types of the late twentieth century, but its relevance to contemporary society is waning as shown by the rise in popularity of big-box retailing. Shopping is continually being reinvented, reformulated, and reshaped to keep up with the subtlest changes in society. ${ }^{56}$ This project is an attempt to reform the space of shopping to reflect the increasingly transnational and diverse ethnoburb population by providing the

\footnotetext{
5541 Weisman.

56 Sze Tsung Leong, “...And Then There Was Shopping” from Harvard Design School Guide to Shopping (New York: Taschen, 2001) 131.
} 
spaces for this group's public life to take place. The redevelopment of suburban landscapes, especially those of the shopping mall, are a pressing issue in the twenty-first century. The adverse ecological and economic effects of sprawling development will be thrust into the forefront as the uncertainty of oil reserves looms and as cities realize the extent of the depletion of the precious resource of open land.

The transnational mobility of ethnoburbs distinguish them from their culturally mainstream counterparts, but, despite this difference, ethnoburbs such as Markham, Ontario, retain much of what is problematic with conventional suburbs such as racial and economic homogeneity and lack of public, democratic space. Perceptions of cultural and economic homogeneity reinforce the hegemonic social structure of both the ethnoburb and mainstream suburbs. This elitist attitude has manifested itself in the built environment of the suburbs as seen in the continued construction of massive tracts of single-family homes. These developments maintain the suburban landscape as one controlled by the automobile-wielding upper-middle classes. By not including provisions for housing of diverse cost, by not providing adequate public gathering space, and by not providing adequate public transportation, these developments disadvantage those unwilling or unable to drive.

As a response to these socio/economic conditions, this architectural project with its cultural anchors and circulation corridors has been designed as a piece of 
social infrastructure overlaid on the existing layout of the mall. This has been done in order to subvert the existing spatial relationship between commercial and social/cultural ventures in which commercial spaces take precedent. Providing spaces for different and even seemingly opposing groups to interact face to face is an important step in the amelioration of strained relationships. It is this limited but vital role that architecture can play in improving the social spaces of the suburban ethnic mall. One such area in this project's design is the food court theatre where show patrons might come in contact with each other, and even share a table with casual onlookers whose original intent for coming to the mall may have been for more retail-oriented purposes.

The physical and cultural landscape of the ethnoburb represents a new challenge for the profession of architecture. Building for communities that are increasingly transnational and mobile in the auto dominated environment of the suburb is an evolving challenge; but the problems facing these communities such as their requirements for public, democratic spaces has been persistent throughout the history of ethnic enclaves in Canada. Victor Gruën's attempt at recreating "Main Street under glass" might have failed in the past in mainstream suburbia, but it is perhaps the ethnoburb's pursuit of appropriate and accessible public space that could finally realize the mall as the social centres they were meant to be. 
APPENDIX A- excerpt from the Canadian Multiculturalism Act

(http://laws.justice.gc.ca/en/C-18.7/226879.html) May, 2006

3. (1) It is hereby declared to be the policy of the Government of Canada to (a) recognize and promote the understanding that multiculturalism reflects the cultural and racial diversity of Canadian society and acknowledges the freedom of all members of Canadian society to preserve, enhance and share their cultural heritage;

(b) recognize and promote the understanding that multiculturalism is a fundamental characteristic of the Canadian heritage and identity and that it provides an invaluable resource in the shaping of Canada's future;

(c) promote the full and equitable participation of individuals and communities of all origins in the continuing evolution and shaping of all aspects of Canadian society and assist them in the elimination of any barrier to that participation;

(d) recognize the existence of communities whose members share a common origin and their historic contribution to Canadian society, and enhance their development;

(e) ensure that all individuals receive equal treatment and equal protection under the law, while respecting and valuing their diversity;

$(f)$ encourage and assist the social, cultural, economic and political institutions of Canada to be both respectful and inclusive of Canada's multicultural character;

(g) promote the understanding and creativity that arise from the interaction between individuals and communities of different origins;

(h) foster the recognition and appreciation of the diverse cultures of Canadian society and promote the reflection and the evolving expressions of those cultures;

(i) preserve and enhance the use of languages other than English and French, while strengthening the status and use of the official languages of Canada; and

(j) advance multiculturalism throughout Canada in harmony with the national commitment to the official languages of Canada. 


\section{BIBLIOGRAPHY}

Anisef, Paul and Michael Lanphier. The World in a City. Toronto: University of Toronto Press, 2003.

Bissoondath, Neil. Selling Illusions: The Cult of Multiculturalism in Canada.

Toronto: Penguin Books, 1994.

Burstein, Meyer. 2000. "Managing Multicultural Issues in Cities." Plan Canada, Vol. 40, No 4: 14-15.

Croucher, Sheila L. "Constructing the Image of Ethnic Harmony In Toronto, Canada: The Politics of Problem Definition and Nondefinition." Urban Affairs Review 32.3 (1997): 319-347.

Gruën, Victor and Larry Smith. Shopping Towns USA: The Planning of Shopping Centers. New York: Van Nostrand Reinhold, 1960.

Goss, Jon. "The 'Magic of the Mall': An Analysis of Form, Function, and Meaning in the Contemporary Retail Built Environment." Annals of the Association of American Geographers, 83.1 (1993): 18-47.

Harney, Robert. Gathering Place: Peoples and Neighbourhoods of Toronto 1834-1945. Toronto: Multicultural History Society of Ontario, 1985.

Herman, Daniel. "Mall" from Harvard Design School Guide to Shopping.

Ed. Rem Koolhaas. New York: Taschen, 2001. 460-475.

Hopkins, J. "West Edmonton Mall as a Centre for Social Interaction." Canadian Geographer, 1991, fall, vol. 35, no. 3, pp268-279.

Keung, Nicholas and Prithi Yelaja. "Knowing the Neighbours." Toronto Star. 23 June 2005: B1, B4-5.

Lai, David. Chinatowns: Towns Within Cities in Canada. Vancouver: University of British Columbia Press, 1988.

Li, Wei. "Los Angeles's Chinese Ethnoburb: From Ethnic Service Center To Global Economy Outpost." Urban Geography, 29.6 (1998): 502-517.

Leong, Sze Tsung. “...And Then There Was Shopping” from Harvard Design Ed. Rem Koolhaas. School Guide to Shopping. New York: Taschen, 2001. 128-155

Leong, Sze Tsung. "Gruën Urbanism" from Harvard Design School Guide to Shopping. Ed. Rem Koolhaas. New York: Taschen, 2001. 380-389. 
Lo, L. and Wang, S. "Settlement patterns of Toronto's Chinese Immigrants: Convergence or Divergence?" Canadian Journal of Regional Science, 20 (1997): 49-72.

McMorrough, John. "City of Shopping" from Harvard Design School Guide to Shopping. Ed. Rem Koolhaas. New York: Taschen, 2001. 192-203.

Miller, Daniel et al. "Shopping, Place and Identity" New York: Routledge, 1998.

Miller, Vincent. "Mobile Chinatowns: The Future of Communities in a Global Space of Flows." Social Issues 2.1 (Jan. 2004). Online. Internet. 2 March 2006. Available: http://www.whb.co.uk/socialissues/vol2vm.htm.

Qadeer, Mohammad, "Ethnic Malls and Plazas: Chinese Commercial Developments in Scarborough, Ontario", Working Paper Series, Toronto: Joint Centre of Excellence for Research on Immigration and Settlement, 1998, 18pp.

Qadeer, Mohammad. 2000. "Urban Planning and Multiculturalism: Beyond Sensitivity." Plan Canada, Vol. 40, No 4: 14-15.

Sandercock, Leonie. Towards Cosmopolis. Toronto: John Wiley and Sons, 1998.

Sibley, David (1992) Outsiders in Society and Space. In Inventing Places: Studies in Cultural Geography, edited by Kay Anderson and Fay Gale, pp. 107-122. Sydney, Australia: Longman Cheshire.

Siemiatycki, Myer and Engin Isin. "Immigration, Diversity and Urban Citizenship in Toronto.” Canadian Journal of Regional Science 22.1.2 (1997): 73-102.

Soja, Edward W. Postmetropolis: Critical Studies of Cities and Regions. Malden, Massachusetts: Blackwell Publishing, 2002.

Thompson, Richard. Toronto's Chinatown: The Changing Social Organization of an Ethnic Community. New York: AMS Press Inc, 198.

Urry, John, "Mobile Sociology." British Journal of Sociology 51.1 (2000) 185-203.

Urry, John. The Tourist Gaze. London: Sage, 2002.

Venturi, Robert, Denis Scott Brown and Steven Izenour. "Learning From Las Vegas." Boston: MIT Press, 1977. 
Walton-Roberts, Margaret. "Transnational Geographies: Indian Immigration to Canada." The Canadian Geographer 47.3 (2003) 235-250.

Weisman, Leslie Kanes. Discrimination by Design: A Feminist Critique of the Man-Made Environment. Urbana, Illinois: University of Illinois Press, 1992.

Wrigley, Neil, and Michelle Lowe. Reading Retail: A Geographical Perspective on Retailing and Consumption Spaces. London: Arnold, 2002. 